\title{
Thermal Synthesis of Polypeptides from $N$-Butyloxycarbonyl Oligopeptides Containing Aspartyl Residue at $C$-Terminus
}

\author{
Toratane Munegumi ${ }^{1}$ and Takafumi Yamada ${ }^{2}$ \\ ${ }^{1}$ Department of Science Education, Naruto University of Education, Naruto, Tokushima 772-8502, Japan \\ ${ }^{2}$ Department of Chemistry, University of Tsukuba, Tsukuba, Ibaraki 305-857, Japan \\ Correspondence should be addressed to Toratane Munegumi; tmunegumi@naruto-u.ac.jp
}

Received 4 January 2017; Revised 22 May 2017; Accepted 12 June 2017; Published 30 July 2017

Academic Editor: Peng He

Copyright (c) 2017 Toratane Munegumi and Takafumi Yamada. This is an open access article distributed under the Creative Commons Attribution License, which permits unrestricted use, distribution, and reproduction in any medium, provided the original work is properly cited.

\begin{abstract}
The thermal reactions of amino acids have been investigated for pure organic synthesis, materials preparation in industry, and prebiotic chemistry. $\mathrm{N}$-t-Butyloxycarbonyl aspartic acid (Boc-Asp) releases 2-butene and carbon dioxide upon heating without solvents. The resulting mixture of the free molten aspartic acid was dehydrated to give peptide bonds. This study describes the thermal reactions of $\mathrm{N}$-t-butyloxycarbonyl peptides (Boc-Gly-L-Asp, Boc-L-Ala-L-Asp, Boc-L-Val-L-Asp, and Boc-Gly-Gly-L-Asp) having an aspartic residue at the carboxyl terminus. The peptides were deprotected upon heating at a constant temperature between 110 and $170^{\circ} \mathrm{C}$ for 1 to $24 \mathrm{~h}$ to afford polypeptides in which the average molecular weight reached 7800 .
\end{abstract}

\section{Introduction}

Polypeptides [1] have been well investigated as protein model compounds [1-8]. Numerous reports on the methodology for the synthesis of polypeptides have been published [1-14]. The $N$-carboxyl- $\alpha$-amino acid anhydride (NCA) method (1) [2, 3 , $9,10]$, polymerization of amino acids using active esters (2) [1, $4-7]$, solid-phase peptide synthesis $(3)[8,12]$, and the heating of amino acids (4) $[13,14]$ are typical examples. The NCA method (1) is suitable for making homopolypeptides and random copolypeptides but is not suitable for the synthesis of sequential copolyamino acid, which is more important for the build-up of functional polypeptides. Sequential polyamino acids have repetitive amino acid residues, in which the amino acid residues can be like -(Gly-Gly-Asp) $n$-. The active ester method (2) [1, 4-7] and solid phase synthesis (3) [8] are more suitable for the synthesis of sequential copolyamino acid. However, the problems of methods (2) and (3) are a long reaction time and the use of much solvent. In contrast, the synthesis of polyamino acid by heating a derivative of the amino acid (4) $[13,14]$ requires neither long reaction time nor solvents.
In previous papers $[15,16]$, we reported the synthesis of homopolypeptides [15] and random copolypeptides [16] upon heating of $\mathrm{N}$-t-butyloxycarbonyl aspartic acid anhydride (Boc-Asp anhydride) and mixtures of Boc-L-Asp, anhydride, and Boc-Gly, Boc-L-Ala, or Boc-Val. In this paper, we report a trial for the synthesis of sequential copolypeptides by the heating of Boc-peptides instead of these anhydrides. As shown in Figures 1 and 2, Boc-peptides (5a-d) and Boc-L-Asp (5e) were prepared for heating under a stream of $\mathrm{N}_{2}$.

\section{Materials and Methods}

2.1. Instrumentation. A nuclear magnetic resonance (NMR) (JEOL FX-100 NMR system (JEOL, Tokyo, Japan)) was used for the collection of ${ }^{1} \mathrm{H}-\mathrm{NMR}$ spectra. A Hitachi model 260-50 infrared (IR) spectrophotometer (Hitachi, Tokyo, Japan) was used for the collection of IR spectra. A Hitachi 200-10 spectrophotometer was used for spectrophotometry measurements.

A Jasco DIP-181 digital polarimeter (Jasco, Tokyo, Japan) was used for the measurement of the optical rotation of the peptide derivatives. A Hitachi 163 gas chromatograph 
hydrogen sulfate to reach a $\mathrm{pH}$ of 2.5 . The resulting solution was extracted with ethyl acetate $(100 \mathrm{~mL}$, three times). The extracts were combined, washed with brine, and dried with anhydrous $\mathrm{MgSO}_{4}$. The resulting ethyl acetate solution was evaporated in vacuo. The obtained precipitate was recrystallized with ethyl acetate and petroleum ether to give $10.1 \mathrm{~g}$ (yield 57\%); the melting point (mp) was $91^{\circ} \mathrm{C}$ (in lit. [19], it is $\left.94-95^{\circ} \mathrm{C}\right) .{ }^{1} \mathrm{H}-\mathrm{NMR}\left(\mathrm{DMSO}_{6}\right): \delta 7.04(\mathrm{t}, \mathrm{J}=6.0 \mathrm{~Hz}$, $\mathrm{H}, \mathrm{NH}), 3.57\left(\mathrm{~d}, J=7.0 \mathrm{~Hz}, 2 \mathrm{H}, \mathrm{CH}_{2}\right), 1.38 \mathrm{ppm}(\mathrm{s}, 9 \mathrm{H}$, $\mathrm{CH}_{3}$ ); IR (KBr, cm $\left.{ }^{-1}\right)$ : 3410, 3350, $3116(\mathrm{NH}), 1750$ (COOH), 1671 (amide I), 1539 (amide II); elementary analysis: Calcd for $\mathrm{C}_{7} \mathrm{H}_{13} \mathrm{NO}_{4}$ : C, 47.99; H, 7.48; N, 8.00\%. Found: C, 48.09; H, $7.58 ; \mathrm{N}, 7.91 \%$.

Other N-t-butyloxycarbonyl-amino acids were prepared in a similar manner. Their physical properties are detailed below.

Boc-L-Ala (2b). Yield 76\%, mp 87-88 ${ }^{\circ} \mathrm{C}$ (lit. [19] 83- $\left.8^{\circ} \mathrm{C}\right) .{ }^{1} \mathrm{H}-$ NMR (DMSO-D $): \delta 7.07(\mathrm{~d}, J=4 \mathrm{~Hz}, 1 \mathrm{H}, \mathrm{NH}), 3.97(\mathrm{q}$, $J=10 \mathrm{~Hz}, 1 \mathrm{H}, \mathrm{CH}), 1.22\left(\mathrm{~d}, J=8.0 \mathrm{~Hz}, 3 \mathrm{H}, \mathrm{CH}_{3}\right), 1.38 \mathrm{ppm}$ $\left(\mathrm{s}, 9 \mathrm{H}, \mathrm{CH}_{3}\right)$. IR $\left(\mathrm{KBr}, \mathrm{cm}^{-1}\right): 3386(\mathrm{NH}), 1742(\mathrm{COOH})$, 1690 (amide I), 1520 (amide II). Elementary analysis: Calcd for $\mathrm{C}_{8} \mathrm{H}_{15} \mathrm{NO}_{4}$ : C, 50.78; H, 7.99; N, 7.40\%. Found: C, 50.78; $\mathrm{H}, 8.10 ; \mathrm{N}, 7.27 \%$. $[\alpha]^{15} \mathrm{D}-24.2$ (c 1.30, acetic acid) (lit. $[\alpha]^{20}{ }_{D}-27$ (c 2.26, acetic acid) [19]).

Boc-L-Val (2c). Yield 93\%, mp 78-79 $\mathrm{C}$ (lit. $\left.80^{\circ} \mathrm{C}[19]\right) .{ }^{1} \mathrm{H}-$ NMR (DMSO-D $\left.)_{6}\right): \delta .90(\mathrm{~d}, J=9.0 \mathrm{~Hz}, 1 \mathrm{H}, \mathrm{NH}), 3.80(\mathrm{~m}$, $1 \mathrm{H}, \mathrm{CH}), 1.84-2.11\left(\mathrm{~m}, 1 \mathrm{H}, \mathrm{CH}_{3}\right), 1.39$ (s, 9H, $\left.\mathrm{CH}_{3}\right), 0.87 \mathrm{ppm}$ $\left(\mathrm{d}, \mathrm{J}=4.0 \mathrm{~Hz}, 6 \mathrm{H}, \mathrm{CH}_{3}\right)$. IR $\left(\mathrm{KBr}, \mathrm{cm}^{-1}\right): 3312(\mathrm{NH}), 1740$ (COOH), 1649 (amide I), 1500 (amide II). Elementary analysis: Calcd for $\mathrm{C}_{10} \mathrm{H}_{19} \mathrm{NO}_{4}$ : C, 55.28; H, 8.81; N, 6.45\%. Found: C, 55.42; H, 8.86; N, 6.45\%. $[\alpha]^{15}-5.1$ (c 0.97 , acetic acid) (lit. $[\alpha]^{20}-5.8$ (c 1.2, acetic acid) $\left.[19]\right)$.

Boc-Gly-Gly (2d). Yield 73\%, mp $138-139^{\circ} \mathrm{C} .{ }^{1} \mathrm{H}-\mathrm{NMR}$ $\left(\mathrm{DMSO}_{6}\right): \delta 8.02(\mathrm{t}, J=6.0 \mathrm{~Hz}, 1 \mathrm{H}, \mathrm{NH}), 6.97(\mathrm{q}, J=$ $6.0 \mathrm{~Hz}, 1 \mathrm{H}, \mathrm{NH}), 3.77\left(\mathrm{~d}, J=5.0 \mathrm{~Hz}, 3 \mathrm{H}, \mathrm{CH}_{2}\right), 3.57(\mathrm{~d}, J=$ $\left.6.0 \mathrm{~Hz}, 2 \mathrm{H}, \mathrm{CH}_{2}\right), 1.38 \mathrm{ppm}\left(\mathrm{s}, 9 \mathrm{H}, \mathrm{CH}_{3}\right)$. IR $\left(\mathrm{KBr}, \mathrm{cm}^{-1}\right): 3362$ (NH), 1742, 1690 (COOH), 1618 (amide I), 1526 (amide II). Elementary analysis: Calcd for $\mathrm{C}_{9} \mathrm{H}_{16} \mathrm{~N}_{2} \mathrm{O}_{5}$ : C, 46.55; $\mathrm{H}, 6.94$; N, 12.06\%. Found: C, 46.70; H, 7.37; N, 12.02\%.

(2) N-t-Butyloxycarbonyl-Amino Acid N-Hydroxysuccinimide (HONSu) Esters $(\mathbf{3 a}-\boldsymbol{d})$

Boc-Gly-ONSu (3a). N-t-Butyloxycarbonyl-glycine (23.73 g, $0.135 \mathrm{~mol}$ ) and $N$-hydroxysuccinimide (HONSu) (17.26 g, $0.15 \mathrm{~mol})$ were dissolved in ethyl acetate $(410 \mathrm{~mL}) . N, N^{\prime}$ dicyclohexylcarbodiimide (DCC) $(34.05 \mathrm{~g}, 0.165 \mathrm{~mol})$ dissolved in ethyl acetate $(60 \mathrm{~mL})$ was added to the cooled ethyl acetate solution at $0^{\circ} \mathrm{C}$. The reaction mixture was stirred for about $36 \mathrm{~h}$ at $0^{\circ} \mathrm{C}$. After the precipitate was filtered off, the obtained filtrate was evaporated in vacuo to give a colorless crystal, which was recrystallized with 2-propanol to give a colorless crystal (18.45 g, 50\%), mp $155^{\circ} \mathrm{C}$ (lit. 168-170 $\mathrm{C}$ [19]). ${ }^{1} \mathrm{H}-\mathrm{NMR}\left(\mathrm{DMSO}_{6}\right): \delta 7.48(\mathrm{t}, J=6.5 \mathrm{~Hz}, 1 \mathrm{H}, \mathrm{NH}), 4.09$ $\left(\mathrm{d}, \mathrm{J}=6.0 \mathrm{~Hz}, 2 \mathrm{H}, \mathrm{CH}_{2}\right), 2.81\left(\mathrm{~s}, 4 \mathrm{H}, \mathrm{CH}_{2}\right), 1.39 \mathrm{ppm}(\mathrm{s}, 9 \mathrm{H}$, $\mathrm{CH}_{3}$ ). IR (KBr, cm ${ }^{-1}$ ): $3302(\mathrm{NH}), 1824,1792$ (ONSu), 1740 (ester). Elementary analysis: Calcd for $\mathrm{C}_{11} \mathrm{H}_{16} \mathrm{~N}_{2} \mathrm{O}_{6}$ : C, 48.53; H, 5.92; N, 10.29\%. Found: C, 48.05; H, 5.90; N, 10.32\%. By the similar manner, the other succinimide esters (3b-d) were prepared as follows.

Boc-L-Ala-ONSu (3b). 91\%, mp $165-167^{\circ} \mathrm{C}$ (lit. $167^{\circ} \mathrm{C}$ [19]). ${ }^{1} \mathrm{H}-\mathrm{NMR}\left(\mathrm{DMSO}-\mathrm{D}_{6}\right): \delta 7.63(\mathrm{~d}, J=7.0 \mathrm{~Hz}, 1 \mathrm{H}, \mathrm{NH}), 4.38$ $(\mathrm{q}, J=7.3 \mathrm{~Hz}, 1 \mathrm{H}, \mathrm{CH}), 3.08\left(\mathrm{~s}, 4 \mathrm{H}, \mathrm{CH}_{2}\right), 1.40(\mathrm{~d}, J=$ 6.0 Hz, 3H, $\left.\mathrm{CH}_{3}\right), 1.39 \mathrm{ppm}\left(\mathrm{s}, 9 \mathrm{H}, \mathrm{CH}_{3}\right)$. IR $\left(\mathrm{KBr}, \mathrm{cm}^{-1}\right): 3296$ (NH), 1827, 1792 (ONSu), 1742 (ester). Elementary analysis: Calcd for $\mathrm{C}_{12} \mathrm{H}_{18} \mathrm{~N}_{2} \mathrm{O}_{6}$ : C, 50.35; H, 6.34; N, 9.79\%. Found: C, 50.52; H, 6.72; N, 9.73\%. [ $\alpha]^{15}{ }_{\mathrm{D}}-48.2$ (c 2.16, 1,4-dioxane) (lit $[\alpha]_{\mathrm{D}}^{20}-49$ (c 2, 1,4-dioxane) [19]).

Boc-L-Val-ONSu (3c). 85\%, mp 131-132 ${ }^{\circ} \mathrm{C}$ (lit. [19] 128-129 ${ }^{\circ} \mathrm{C}$ ). ${ }^{1} \mathrm{H}-\mathrm{NMR}\left(\mathrm{DMSO}^{-\mathrm{D}_{6}}\right): \delta 7.57(\mathrm{~d}, J=7.0 \mathrm{~Hz}, 1 \mathrm{H}, \mathrm{NH}), 4.23$ $(\mathrm{d}, J=5.0 \mathrm{~Hz}, 1 \mathrm{H}, \mathrm{CH}), 2.81\left(\mathrm{~s}, 4 \mathrm{H}, \mathrm{CH}_{2}\right), 2.05-2.26(\mathrm{~m}$, $1 \mathrm{H}, \mathrm{CH}), 1.41\left(\mathrm{~s}, 9 \mathrm{H}, \mathrm{C} \mathrm{CH}_{3}\right), 1.00 \mathrm{ppm}(\mathrm{d}, J=7.0 \mathrm{~Hz}, 6 \mathrm{H}$, $\left.\mathrm{CH}_{3}\right)$. IR $\left(\mathrm{KBr}, \mathrm{cm}^{-1}\right): 3354(\mathrm{NH}), 1810,1783(\mathrm{ONSu}), 1742$ (ester), 1671 (amide I), 1539 (amide II). Elementary analysis: Calcd for $\mathrm{C}_{14} \mathrm{H}_{22} \mathrm{~N}_{2} \mathrm{O}_{6}$ : C, 53.49; H, 7.05; N, 8.91\%. Found: C, 53.56; H, 7.19; N, 8.84\%. [ $\alpha]^{15}$ D -23.4 (c 1.81, 1,4-dioxane) (lit. $[\alpha]_{\mathrm{D}}^{20}-37.0$ (c 2, 1,4-dioxane) [19]).

Boc-Gly-Gly-ONSu (3d). $71 \%, \quad \mathrm{mp} \quad 164-165^{\circ} \mathrm{C} .{ }^{1} \mathrm{H}-\mathrm{NMR}$ $\left(\mathrm{DMSO}_{6}\right): \delta 8.45(\mathrm{t}, J=6.0 \mathrm{~Hz}, 1 \mathrm{H}, \mathrm{NH}), 7.19(\mathrm{t}, J=10 \mathrm{~Hz}$, $1 \mathrm{H}, \mathrm{NH}), 4.26\left(\mathrm{~d}, J=6.0 \mathrm{~Hz}, 2 \mathrm{H}, \mathrm{CH}_{2}\right), 3.60(\mathrm{~d}, J=7.0 \mathrm{~Hz}$, $2 \mathrm{H}, \mathrm{CH}_{2}$ ), 2.82 (s, $\left.4 \mathrm{H}, \mathrm{CH}_{2}\right), 1.39 \mathrm{ppm}\left(\mathrm{s}, 9 \mathrm{H}, \mathrm{CH}_{3}\right)$. IR ( $\mathrm{KBr}$, $\mathrm{cm}^{-1}$ ): 3416, 3300 (NH), 1825, 1792 (ONSu), 1742 (ester), 1702, 1665 (amide I), 1576, 1516 (amide II). Elementary analysis: Calcd for $\mathrm{C}_{13} \mathrm{H}_{19} \mathrm{~N}_{3} \mathrm{O}_{7}$ : C, 47.42; $\mathrm{H}, 5.82 ; \mathrm{N}, 12.76 \%$. Found: C, $47.50 ; \mathrm{H}, 5.88 ; \mathrm{N}, 12.63 \%$.

\section{(3) N-t-Butyloxycarbonyl-Peptides $(\mathbf{5 a}-\boldsymbol{d})$}

TsOH L-Asp $(\mathrm{OBzl})_{2}$ (4). L-Aspartic acid (1e) (19.97 g, $0.150 \mathrm{~mol})$, p-toluenesulfonic acid monohydrate 1 (29.10 g, $0.153 \mathrm{~mol})$, benzyl alcohol $(300 \mathrm{~mL})$, and benzene $(300 \mathrm{~mL})$ were mixed in a three-necked flask that was connected to a Dean-Stark apparatus. The esterification reaction was carried out by refluxing the reaction mixture and removing water in the flask for 7 days. The cooled reaction solution was evaporated in vacuo to give a colorless solid, which was recrystallized with chloroform and petroleum ether. Yield $49.8 \mathrm{~g}$ (68\%), mp $157-158^{\circ} \mathrm{C}$ (lit. $159-160^{\circ} \mathrm{C}$ [19]). ${ }^{1} \mathrm{H}-\mathrm{NMR}$ $\left(\mathrm{DMSO}_{6}\right): \delta 8.54\left(\mathrm{~s}, 1 \mathrm{H}, \mathrm{SO}_{3} \mathrm{H}\right), 7.51(\mathrm{~d}, J=10 \mathrm{~Hz}, 2 \mathrm{H}$, ArH), 7.36 (s, 10H, ArH), 7.11 (d, $J=9.0 \mathrm{~Hz}, 2 \mathrm{H}, \mathrm{ArH}), 5.14$ $\left(\mathrm{d}, J=8.0 \mathrm{~Hz}, 2 \mathrm{H}, \mathrm{NH}_{2}\right), 4.50(\mathrm{t}, J=5.5 \mathrm{~Hz}, 1 \mathrm{H}, \mathrm{CH})$, $3.40\left(\mathrm{~s}, 4 \mathrm{H}, \mathrm{CH}_{2}\right), 3.05\left(\mathrm{~d}, J=8.0 \mathrm{~Hz}, 2 \mathrm{H}, \mathrm{CH}_{2}\right), 2.28 \mathrm{ppm}$ $\left(\mathrm{s}, 3 \mathrm{H}, \mathrm{CH}_{3}\right)$. IR $\left(\mathrm{KBr}, \mathrm{cm}^{-1}\right): 3042\left(\mathrm{NH}_{3}\right), 1758,1738,1127$ (ester), 1185 (-SO3), 814, 739, 685. Elementary analysis: Calcd for $\mathrm{C}_{25} \mathrm{H}_{27} \mathrm{NO}_{7} \mathrm{~S}$ : C, 61.84; $\mathrm{H}, 5.61 ; \mathrm{N}, 2.89 \%$. Found: C, 61.94; H, 5.63; N, 2.85\%. [ $\alpha]^{15}{ }_{\mathrm{D}}-1.04$ (c 2.21, methanol) (lit. $[\alpha]_{\mathrm{D}}^{25}+1.0$ (c 1, methanol) [19]).

Boc-Gly-L-Asp (5a). L-Aspartic acid (1e) (7.98 g, $0.060 \mathrm{~mol}$ ) and triethylamine $\left(\mathrm{NEt}_{3}\right)(12.14 \mathrm{~g}, 0.12 \mathrm{~mol})$ were dissolved in distilled water $(250 \mathrm{~mL})$, and Boc-Gly-ONSu (13.61 g, $0.050 \mathrm{~mol}$ ) dissolved in 1,4 -dioxane $(250 \mathrm{~mL})$ for $4 \mathrm{~h}$ was 
added to the solution. The resulting solution, which was acidified with $10 \% \mathrm{KHSO}_{4}$ to give a $\mathrm{pH}$ of 2.5 , was extracted with ethyl acetate $(100 \mathrm{~mL}$, three times). The combined extracts were washed with brine and dried with anhydrous $\mathrm{MgSO}_{4}$. The filtrated solution was evaporated in vacuo to give a colorless crystal that was recrystallized with ethyl acetate and petroleum ether to yield $10.17 \mathrm{~g}(70 \%) ; \mathrm{mp} 1300^{\circ} \mathrm{C}$; ${ }^{1} \mathrm{H}$ NMR (DMSO-D $): \delta 8.02(\mathrm{~d}, J=8.0 \mathrm{~Hz}, 1 \mathrm{H}, \mathrm{NH}), 6.96(\mathrm{t}$, $J=4.0 \mathrm{~Hz}, 1 \mathrm{H}, \mathrm{NH}), 4.56(\mathrm{t}, J=10 \mathrm{~Hz}, 1 \mathrm{H}, \mathrm{CH}), 3.56(\mathrm{q}$, $\left.J=2.0 \mathrm{~Hz}, 2 \mathrm{H}, \mathrm{CH}_{2}\right), 2.66\left(\mathrm{~d}, J=6.0 \mathrm{~Hz}, 2 \mathrm{H}, \mathrm{CH}_{2}\right), 1.38 \mathrm{ppm}$ $\left(\mathrm{s}, 9 \mathrm{H}, \mathrm{CH}_{3}\right)$. IR $\left(\mathrm{KBr}, \mathrm{cm}^{-1}\right)$ : 3432, $3340(\mathrm{NH}), 1756,1711$ (COOH), 1659 (amide I), 1547 (amide II). Elementary analysis: Calcd for $\mathrm{C}_{11} \mathrm{H}_{18} \mathrm{~N}_{2} \mathrm{O}_{7}$ : C, 45.52; H, 6.25; N, 9.65\%. Found: C, 45.43; H, 6.35; N, 9.48\%. [ $\alpha]^{15}{ }_{D}+20.7$ (c 1.06, acetic acid).

Boc-L-Ala-L-Asp (5b). Boc-L-Ala-ONSu (3b) (0.020 mol) was coupled with $\mathrm{TsOH} \mathrm{L-Asp}(\mathrm{OBzl})_{2}(4)$ in dichloromethane to yield Boc-L-Ala-L-Asp $(\mathrm{OBzl})_{2}$ of $84 \%$, which was hydrogenolyzed over $5 \% \mathrm{Pd}$ on charcoal to yield Boc-LAla-L-Asp. Yield: $3.21 \mathrm{~g}, 70 \%, 85^{\circ} \mathrm{C}$ (decomposed). ${ }^{1} \mathrm{H}-\mathrm{NMR}$ $\left(\mathrm{DMSO}_{6}\right): \delta 7.97(\mathrm{~d}, J=8.0 \mathrm{~Hz}, 1 \mathrm{H}, \mathrm{NH}), 6.94(\mathrm{~d}, J=$ $7.0 \mathrm{~Hz}, 1 \mathrm{H}, \mathrm{NH}), 4.50(\mathrm{t}, J=10 \mathrm{~Hz}, 1 \mathrm{H}, \mathrm{CH}), 3.95(\mathrm{q}, J=$ $7.0 \mathrm{~Hz}, 2 \mathrm{H}, \mathrm{CH}), 2.63\left(\mathrm{~d}, J=6.0 \mathrm{~Hz}, 2 \mathrm{H}, \mathrm{CH}_{2}\right), 1.37(\mathrm{~s}, 9 \mathrm{H}$, $\left.\mathrm{CH}_{3}\right), 1.17 \mathrm{ppm}\left(\mathrm{d}, J=7.0 \mathrm{~Hz}, 3 \mathrm{H}, \mathrm{CH}_{3}\right)$. IR $\left(\mathrm{KBr}, \mathrm{cm}^{-1}\right)$ : 3432, $3340(\mathrm{NH}), 1756,1711(\mathrm{COOH}), 1659$ (amide I), 1547 (amide II). Elementary analysis: Calcd for $\mathrm{C}_{12} \mathrm{H}_{20} \mathrm{~N}_{2} \mathrm{O}_{7}$ 0.45THF: C, 49.22; H, 7.06; N, 8.32\%. Found: C, 48.98; H, 7.09; $\mathrm{N}, 8.07 \% .[\alpha]^{15} \mathrm{D}+3.81$ (c 0.972 , acetic acid). Other substrates $(\mathbf{5 c}, 5 \mathbf{d})$ were prepared in a similar manner.

Boc-L-Val-L-Asp (5c). 72\%, mp $85^{\circ} \mathrm{C}$ (decompose). ${ }^{1} \mathrm{H}-\mathrm{NMR}$ $\left(\mathrm{DMSO}_{6} \mathrm{D}_{6}\right): \delta 8.10(\mathrm{~d}, J=7.0 \mathrm{~Hz}, 1 \mathrm{H}, \mathrm{NH}), 6.65(\mathrm{~d}, J=$ $9.0 \mathrm{~Hz}, 1 \mathrm{H}, \mathrm{NH}), 4.53(\mathrm{t}, J=10 \mathrm{~Hz}, 1 \mathrm{H}, \mathrm{CH}), 3.83(\mathrm{~d}, J=$ $2.0 \mathrm{~Hz}, 1 \mathrm{H}, \mathrm{CH}), 2.65\left(\mathrm{~d}, J=9.0 \mathrm{~Hz}, 2 \mathrm{H}, \mathrm{CH}_{2}\right), 1.70-1.83(\mathrm{~m}$, $1 \mathrm{H}, \mathrm{CH}), 1.38\left(\mathrm{~s}, 9 \mathrm{H}, \mathrm{CH}_{3}\right), 0.86\left(\mathrm{~d}, J=6.0 \mathrm{~Hz}, 3 \mathrm{H}, \mathrm{CH}_{3}\right)$, $0.80 \mathrm{ppm}\left(\mathrm{d}, J=6.0 \mathrm{~Hz}, 3 \mathrm{H}, \mathrm{CH}_{3}\right)$. IR $\left(\mathrm{KBr}, \mathrm{cm}^{-1}\right): 3432,3340$ $(\mathrm{NH}), 1756,1711(\mathrm{COOH}), 1659$ (amide I), 1547 (amide II). Elementary analysis: Calcd for $\mathrm{C}_{14} \mathrm{H}_{24} \mathrm{~N}_{2} \mathrm{O}_{7}$ 0.45THF: C, 52.02; H, 7.63; N, 7.68\%. Found: C, 52.03; H, 7.60; N, 7.41\%. $[\alpha]^{15}-5.67$ (c 1.04, acetic acid).

Boc-Gly-Gly-L-Asp (5d). 97\%, mp 82-92 ${ }^{\circ} \mathrm{C} . \quad{ }^{1} \mathrm{H}-\mathrm{NMR}$ $\left(\right.$ DMSO-D $\left._{6}\right): \delta 8.20(\mathrm{~d}, J=8.0 \mathrm{~Hz}, 1 \mathrm{H}, \mathrm{NH}), 8.02(\mathrm{t}$, $J=2.5 \mathrm{~Hz}, 1 \mathrm{H}, \mathrm{NH}), 7.10(\mathrm{t}, J=11 \mathrm{~Hz}, 1 \mathrm{H}, \mathrm{NH}), 4.55(\mathrm{t}$, $J=10 \mathrm{~Hz}, 1 \mathrm{H}, \mathrm{CH}), 3.75\left(\mathrm{~d}, J=5.0 \mathrm{~Hz}, 2 \mathrm{H}, \mathrm{CH}_{2}\right), 3.57(\mathrm{~d}$, $\left.J=6.0 \mathrm{~Hz}, 2 \mathrm{H}, \mathrm{CH}_{2}\right), 2.64\left(\mathrm{~d}, J=0.2 \mathrm{~Hz}, 2 \mathrm{H}, \mathrm{CH}_{2}\right), 1.39 \mathrm{ppm}$ (s, 9H, $\left.\mathrm{CH}_{3}\right)$. IR $\left(\mathrm{KBr}, \mathrm{cm}^{-1}\right): 3354(\mathrm{NH}), 1725(\mathrm{COOH}), 1657$ (amide I), 1535 (amide II). Elementary analysis: Calcd for $\mathrm{C}_{13} \mathrm{H}_{21} \mathrm{~N}_{3} \mathrm{O}_{8}$ 0.50THF: C, 46.99; H, 6.57; N, 10.96\%. Found: C, $47.05 ; \mathrm{H}, 6.56 ; \mathrm{N}, 10.85 \%$. $[\alpha]^{15}{ }_{\mathrm{D}}+16.2$ (c 1.04 , acetic acid).

Boc-L-Asp (5e). 60\%, mp 116-118 $\mathrm{C}$ (lit. [19] 118-119 $\mathrm{C}$ ). ${ }^{1} \mathrm{H}-$ $\operatorname{NMR}\left(\right.$ DMSO$\left._{-} \mathrm{D}_{6}\right): \delta 7.02(\mathrm{~d}, J=8.0 \mathrm{~Hz}, 1 \mathrm{H}, \mathrm{NH}), 4.26(\mathrm{q}, J=$ $7.3,15 \mathrm{~Hz}, 1 \mathrm{H}, \mathrm{CH}), 2.63\left(\mathrm{~d}, J=4.0 \mathrm{~Hz}, 2 \mathrm{H}, \mathrm{CH}_{2}\right.$ ), $1.38 \mathrm{ppm}(\mathrm{s}$, 9H, $\left.\mathrm{C} \mathrm{CH}_{3}\right)$. IR ( $\left.\mathrm{KBr}, \mathrm{cm}^{-1}\right): 3358(\mathrm{NH}), 1720$ (COOH), 1694 (amide I), 1539 (amide II). Elementary analysis: Calcd for $\mathrm{C}_{9} \mathrm{H}_{15} \mathrm{NO}_{6}$ : C, 46.35; H, 6.48; N, 6.01\%. Found: C, 46.37; H, 6.59; N, 5.85\%. $[\alpha]^{15}{ }_{\mathrm{D}}-4.5$ (c 1.15, methanol) (lit. $[\alpha]_{\mathrm{D}}^{20}-6.4$ (c 1, methanol) [19]).
2.3. Thermal Analysis. A small scale of the reaction was performed in the thermal analyzer using the substrate under an $\mathrm{N}_{2}$ stream to monitor the thermal gravimetry (TG) and differential thermal analysis (DTA); Boc-Gly-L-Asp $\left(3.30 \mathrm{mg}\right.$ ) was heated from $50^{\circ} \mathrm{C}$ to $175^{\circ} \mathrm{C}$ at a rate of $4.7^{\circ} \mathrm{C}$ per min. The gas mixture that formed during the heating reaction was directly derived into a mass spectrometer (Shimadzu $\mathrm{QP}-1000 \mathrm{~A})$. The gases were determined by selective ion monitoring as $\mathrm{CO}_{2}(\mathrm{~m} / z=44)$, isobutene $(\mathrm{m} / z=56)$, and water $(m / z=18)$.

2.4. Thermal Reaction. $N$-Boc-dipeptides (5a-5c, $0.5 \mathrm{mmol})$ and $N$-Boc-tripeptide (5d, $0.3 \mathrm{mmol})$, which were put into different Pyrex test tubes $(165 \mathrm{~mm} \times 18$ internal diameter (i.d.)), were kept for 5 min under $\mathrm{N}_{2}$ flow and then heated in an oil bath controlled at a constant temperature under $\mathrm{N}_{2}$ flow. After the heating reactions, the reaction mixtures in the test tubes were kept under vacuum for $24 \mathrm{~h}$ at room temperature. The weight decrease and IR spectra of the resulting samples were measured.

2.5. Gel Filtration. The overall amount of each reaction mixture after the heating reaction was dissolved in $5 \mathrm{~mL}$ of $0.5 \mathrm{M}$ acetic acid and the resulting solution was loaded onto a gel permeation chromatograph ( $910 \mathrm{~mm} \times 15 \mathrm{~mm}$ i.d.). During the elution with $0.5 \mathrm{M}$ acetic acid, the eluate was collected by $3 \mathrm{~mL}$ fractions in 95 test tubes. The ultraviolet (UV) absorption of each collected fraction was recorded at $230 \mathrm{~nm} .3 \mathrm{M}$ acetic acid was used only for the reaction mixture using Boc-L-Val-L-Asp (5c) instead of $0.5 \mathrm{M}$ acetic acid.

2.6. Molecular Weight Estimation. The collected fractions were tested for ninhydrin using thin-layer chromatography in a developing solvent: 1-butanol-acetic acid-water $(4: 1: 2(\mathrm{v} / \mathrm{v}))$. Ninhydrin-negative fractions were combined as higher molecular weight fractions, and ninhydrin-positive fractions were combined as lower molecular weight fractions, which showed not a spot but a tailed area with $R f$ values in the range from 0 to $\mathrm{ca}$. 0.4 . The higher molecular weight fractions were lyophilized to afford an amorphous peptide powder, of which a part (1 to $2 \mathrm{mg}$ ) was dissolved in $0.1 \mathrm{M}$ sodium phosphate buffer $\left(\mathrm{NaH}_{2} \mathrm{PO}_{4}-\mathrm{Na}_{2} \mathrm{HPO}_{4}, \mathrm{pH}\right.$ 6.9). A part $(20 \mu \mathrm{L})$ of the sample solution was mixed with $20 \mu \mathrm{L}$ blue dextran solution $(1.5 \mathrm{mg} / \mathrm{mL} 0.1 \mathrm{M}$ sodium phosphate buffer $\mathrm{pH}$ 6.9) and was injected into the TSK gel G-3000 PW in an HPLC system. The retention of the sample on the chromatogram was compared with the calibration line that was prepared with several retention times of proteins of known molecular weight.

2.7. Hydrolysis of Polypeptides and Amino Acid Analysis. About $2 \mathrm{mg}$ of each higher molecular weight fraction described in Section 2.5 was mixed with $2 \mathrm{~mL}$ of $6 \mathrm{M}-\mathrm{HCl}$ in a glass test tube that was sealed under vacuum. The sealed glass was heated to $110^{\circ} \mathrm{C}$ and held for $8 \mathrm{~h}$, which was enough for the complete hydrolysis of the sample peptide. The resulting hydrolysate was analyzed by means of the automatic amino acid analyzer. 


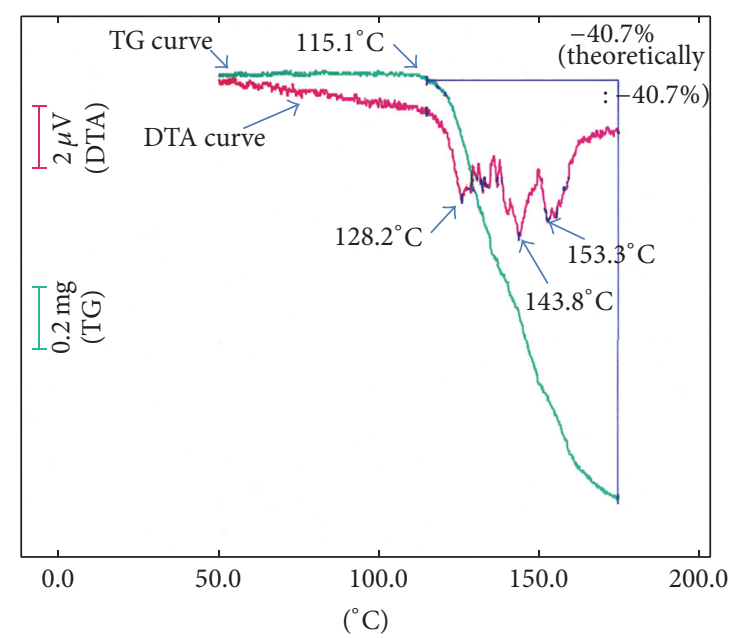

FIGURE 3: Thermal analysis of Boc-Gly-L-Asp (5a). Heating rate: $4.7^{\circ} \mathrm{C} / \mathrm{min}$; carrier gas: $\mathrm{He}, 50 \mathrm{~mL} / \mathrm{min}$; AMP range: DTA: $200 \mu \mathrm{V}$; TG: $10 \mathrm{mg}$ on a Pt cell $(2.65 \mathrm{~mm} \times 5.40$ i.d. $)$.

2.8. D/L Ratio Analysis. $1 \mathrm{~mL}$ of each acid-hydrolysate described above was put in a glass vial and kept under a vacuum. The obtained constant weight of the sample was esterified with $2 \mathrm{~mL}$ of 2-propanol solution containing $1.5 \mathrm{M} \mathrm{HCl}$ and then with trifluoroacetic anhydride to give $\mathrm{N}$-trifluoroamino acid 2-propyl ester (N-TFA-AA-O-2-Pr).

\section{Results and Discussion}

3.1. Weight Decrease and Ion Monitoring during the Heating Reactions of Boc-Peptides and Boc-L-Asp. The charts of DTA and TG for Boc-Gly-L-Asp (5a) are shown in Figure 3.

Although the DTA line curved gently down during the time the TA line was flat, both lines go rapidly down after the temperature of $115^{\circ} \mathrm{C}$ was reached, which corresponded with a temperature a little lower than the $\mathrm{mp}\left(130^{\circ} \mathrm{C}\right)$. The thermal absorption on the DTA line continued and became almost flat at $175^{\circ} \mathrm{C}$. The TG line also became flat and the total decrease in weight was $40.7 \%$ at $175^{\circ} \mathrm{C}$. This ratio corresponds to the theoretical weight decrease after the decomposition of the Boc group (34.5\%) and dehydration (6.2\%) between free peptides from the initial weight of the Boc-Gly-L-Asp compound. To monitor the evolved gases during the heating reaction of Boc-Gly-L-Asp, the thermal analyzer was directly connected to a mass spectrometer (MS). The MS records showed 2-butene $(m / z=56), \mathrm{CO}_{2}(m / z=44)$, and water $(m / z=18)$ at temperature conditions higher than about $110^{\circ} \mathrm{C}$ (Figure 4). Monitoring water generation on the line, there were two peaks of water. The peak at the lower temperatures seems to be the water generation during the peptide bond formation between deprotected dipeptides. Another peak at the higher temperatures is supposed to be the water generation during the imide formation.

As a control experiment, the thermal analysis of Boc-LAsp was conducted during monitoring the generated gases by mass spectrometry as shown in Figures 5 and 6.
The curves of TA and DTA of Boc-L-Asp in Figure 5 show almost flat lines (the first flat) from room temperature to $100^{\circ} \mathrm{C}$ and then a rapid decrease of weight on TA plus an energy absorption peak on DTA. In the range of higher temperatures, the curve of DTA became flat again (the second flat) at $180^{\circ} \mathrm{C}$ and rapidly falls down and then is flat (the third flat) at $216^{\circ} \mathrm{C}$. The weight decrease from the first to the second flat corresponds with $49.2 \%$ of the initial weight of BocGly-L-Asp. The theoretical weight decrease is caused almost totally $(50.7 \%)$ by 2 -butene (24.1\%), $\mathrm{CO}_{2}$ (18.9\%), and water (7.7\%). These gases were monitored in the lower temperature range up to $180^{\circ} \mathrm{C}$ (Figure 6). The weight decrease (11.5\%) from the second to the third flat may include generation of water $(7.7 \%)$ by imide formation and a little decomposition. The temperature range of the weight decrease (11.5\%) corresponded to the energy absorption peak on the DTA curve (Figure 5) and the second peak of water generation in Figure 6.

Compared with the thermal analyses of Boc-Gly-L-Asp and Boc-L-Asp, the dehydration in the thermal reaction of Boc-Gly-L-Asp might proceed at temperatures lower than those of the thermal reaction of Boc-L-Asp [15, 20], which did not produce peptides but amino acid at lower temperatures. A similar feature was observed for Boc-DL-Asp [20] and Boc-L-asparagine (Boc-L-Asn) [21]. The latter case released ammonia as well as 2-butene, $\mathrm{CO}_{2}$, and water.

3.2. Thermal Reactions of N-Boc-Peptides $(\mathbf{5 a}-\mathbf{5} \boldsymbol{d})$. Table 1 shows the weight decrease during the heating reactions of $N$-Boc-peptides under different conditions. The heating reaction of Boc-Gly-L-Asp under these conditions gave about $37 \%$ to $46 \%$ weight decrease, almost equal to the total release (41\%) of 2-butene, $\mathrm{CO}_{2}$, and water. Boc-L-Ala-L-Asp, BocL-Val-L-Asp, and Boc-Gly-Gly-L-Asp theoretically release 2butene, $\mathrm{CO}_{2}$, and water at the ratio of $39 \%, 34 \%$, and $29 \%$, respectively. At temperatures below $130^{\circ} \mathrm{C}$, these compounds showed a lower decrease than the theoretical decrease. The reactions of these substrates at $130^{\circ} \mathrm{C}$ for $4 \mathrm{~h}$ are enough for the complete release of Boc and water.

3.3. Gel Filtration of Reaction Mixtures. The thermal reaction products were loaded onto a gel permeation chromatograph. A constant volume (ca. $3 \mathrm{~mL}$ ) of eluate was added to the test tubes. Figures 7-9 show the absorbance of each collected eluate at $230 \mathrm{~nm}$ plotted against the test tube number, which was proportional to the total volume of elution after the start of loading.

Figure 7 shows chromatograms of the reaction mixtures of Boc-Gly-L-Asp at $130^{\circ} \mathrm{C}$ for varying reaction times. Two peaks appear in each chromatogram. The first and the second peaks included the higher and lower molecular weight fraction, respectively. The first peak is revealed faster with the reaction time proceeded until $8 \mathrm{~h}$ reaction (d) and is revealed later after $8 \mathrm{~h}$ reaction. The results suggested that the polymerization reaction mainly proceeded during $8 \mathrm{~h}$ and degradation proceeded mainly after $8 \mathrm{~h}$.

Figure 8 shows the chromatograms of the heating reaction mixtures of Boc-Gly-L-Asp (5a) at varying temperatures. Comparing the first peaks of chromatograms ((a) and (b)) at 


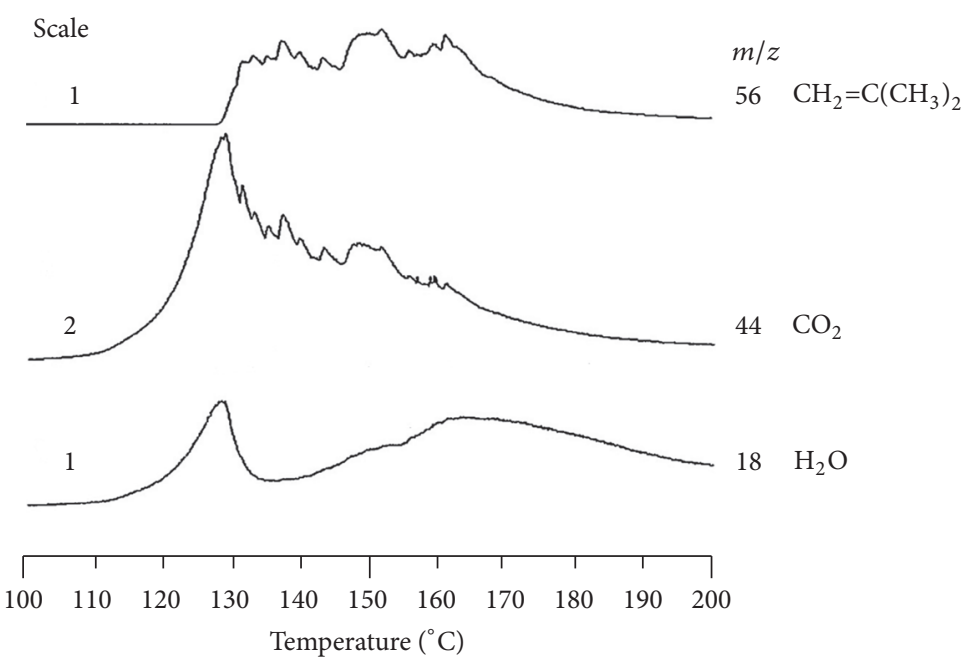

FIGURE 4: Thermal release patterns of ions for compounds from Boc-Gly-L-Asp (5a) by DTA/TG-MS analysis. Ion source: EI, 70 eV; temperature: $250^{\circ} \mathrm{C}$. Detection: EI range, $\mathrm{m} / z=17$ to 100 ; interval, $1.5 \mathrm{~s}$; gain, 2.5 ; pipe heater: $280^{\circ} \mathrm{C}$. GC oven: $150^{\circ} \mathrm{C}$; injection: $200^{\circ} \mathrm{C}$.

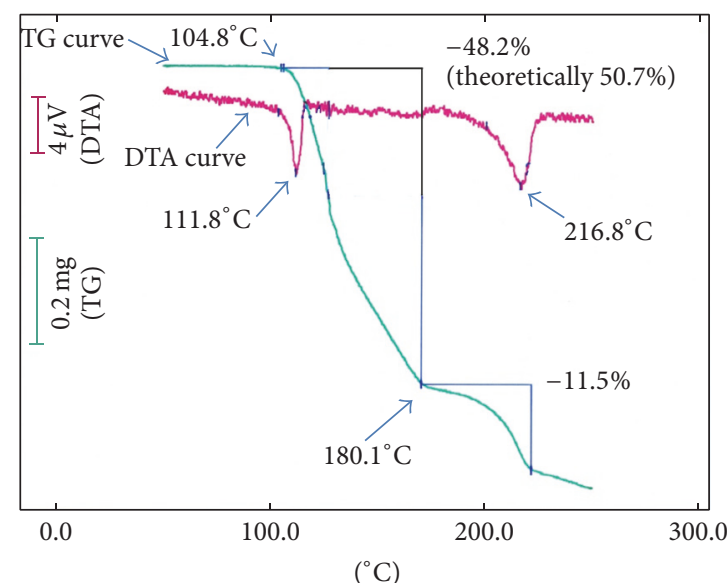

FIgURE 5: Thermal analysis of Boc-L-Asp (5e). Heating rate: $4.7^{\circ} \mathrm{C} / \mathrm{min}$; carrier gas: $\mathrm{He}, 50 \mathrm{~mL} / \mathrm{min}$; AMP range: DTA (differential thermal analysis): $200 \mu \mathrm{V}$, TG (thermogravimetry): $10 \mathrm{mg}$ on a platinum cell $(2.65 \mathrm{~mm} \times 5.40$ i.d.).

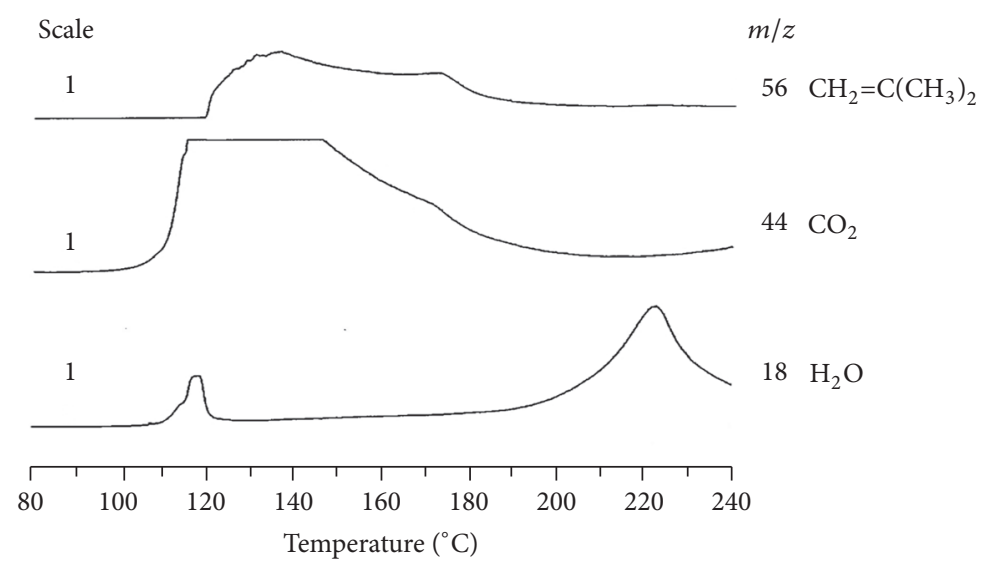

FIGURE 6: Thermal release patterns of ions for compounds from Boc-L-Asp (5a) by DTA/TG-MS analysis. Ion source: EI, $70 \mathrm{eV}$; temperature: $250^{\circ} \mathrm{C}$. Detection: EI range, $\mathrm{m} / z=17$ to 100 ; interval, $1.5 \mathrm{sec}$; gain, 2.5. Pipe heater: $280^{\circ} \mathrm{C}$. GC oven: $150^{\circ} \mathrm{C}$; injection: $200^{\circ} \mathrm{C}$. 
TABLE 1: Weight decrease in the heating reaction of substrate peptides.

\begin{tabular}{|c|c|c|c|c|c|c|}
\hline \multirow{2}{*}{ Substrate } & \multirow{2}{*}{ Temperature $/{ }^{\circ} \mathrm{C}$} & \multirow{2}{*}{ Reaction time/h } & \multicolumn{2}{|c|}{ Weight/mg } & \multicolumn{2}{|c|}{ Weight decrease } \\
\hline & & & Initial & Later & $\mathrm{mg}$ & $\%$ \\
\hline \multirow{10}{*}{ Boc-Gly-L-Asp (5a) } & 110 & 24 & 145 & 88 & 57 & 39 \\
\hline & 120 & 24 & 145 & 89 & 56 & 39 \\
\hline & 130 & 1 & 145 & 92 & 53 & 37 \\
\hline & 130 & 2 & 143 & 86 & 57 & 40 \\
\hline & 130 & 4 & 146 & 86 & 60 & 41 \\
\hline & 130 & 8 & 146 & 83 & 63 & 43 \\
\hline & 130 & 16 & 148 & 84 & 64 & 43 \\
\hline & 130 & 24 & 145 & 84 & 61 & 42 \\
\hline & 150 & 2 & 146 & 81 & 65 & 45 \\
\hline & 170 & 2 & 147 & 80 & 67 & 46 \\
\hline \multirow{6}{*}{ Boc-L-Ala-L-Asp (5b) } & 120 & 1 & 161 & 120 & 41 & 25 \\
\hline & 120 & 2 & 151 & 117 & 34 & 23 \\
\hline & 120 & 4 & 162 & 121 & 41 & 25 \\
\hline & 130 & 1 & 146 & 92 & 54 & 37 \\
\hline & 130 & 2 & 174 & 100 & 74 & 43 \\
\hline & 130 & 4 & 179 & 99 & 80 & 45 \\
\hline \multirow{9}{*}{ Boc-L-Val-L-Asp (5c) } & 110 & 1 & 164 & 160 & 4 & 2 \\
\hline & 110 & 2 & 160 & 132 & 28 & 18 \\
\hline & 110 & 4 & 163 & 126 & 37 & 23 \\
\hline & 120 & 1 & 161 & 134 & 27 & 17 \\
\hline & 120 & 2 & 186 & 160 & 26 & 14 \\
\hline & 120 & 4 & 169 & 115 & 54 & 32 \\
\hline & 130 & 1 & 170 & 141 & 29 & 17 \\
\hline & 130 & 2 & 165 & 116 & 49 & 30 \\
\hline & 130 & 4 & 166 & 109 & 57 & 34 \\
\hline \multirow{6}{*}{ Boc-Gly-Gly-L-Asp (5d) } & 120 & 1 & 113 & 107 & 6 & 5 \\
\hline & 120 & 2 & 107 & 99 & 8 & 7 \\
\hline & 120 & 4 & 110 & 74 & 36 & 33 \\
\hline & 130 & 1 & 109 & 80 & 29 & 27 \\
\hline & 130 & 2 & 104 & 69 & 35 & 34 \\
\hline & 130 & 4 & 104 & 71 & 33 & 32 \\
\hline
\end{tabular}

different temperatures, the first peak on (b) $\left(120^{\circ} \mathrm{C}, 24 \mathrm{~h}\right)$ was revealed faster than $(\mathrm{a})\left(110^{\circ} \mathrm{C}, 24 \mathrm{~h}\right)$. The result suggested that the condition at $120^{\circ} \mathrm{C}, 24 \mathrm{~h}$, was better for polymerization than $110^{\circ} \mathrm{C}, 24 \mathrm{~h}$. Comparing the first peaks of chromatograms ((c) and (d)) at different temperatures, the first peak of (c) $\left(150^{\circ} \mathrm{C}, 2 \mathrm{~h}\right)$ was revealed faster than $(\mathrm{a})\left(170^{\circ} \mathrm{C}, 2 \mathrm{~h}\right)$. The result suggested that the condition at $150^{\circ} \mathrm{C}, 2 \mathrm{~h}$, was better for polymerization than $170^{\circ} \mathrm{C}, 2 \mathrm{~h}$. A high temperature, such as $170^{\circ} \mathrm{C}$, fostered the degradation of polymers generated from the substrate Boc-Gly-L-Asp (5a).

The chromatograms of the reaction mixture using other substrates (5b-d) are shown in Figure 9. The chromatograms of $5 \mathbf{b}$ and $5 \mathbf{c}$ showed two peaks, although the chromatogram of the reaction mixture of $\mathbf{5 c}$ shows a not-so-clear second peak. This might have been caused by the use of an eluate with a higher concentration of acetic acid $(3 \mathrm{M})$ which had stronger absorption than $0.5 \mathrm{M}$ acetic acid at $230 \mathrm{~nm}$ but could enable the reaction mixture to dissolve in it.
The IR spectrum (Figure 10) of the higher molecular weight products shows the absorption of typical acidic polypeptides: amide I, amide II, - $\mathrm{NH}$, and - $\mathrm{COOH}$ groups.

3.4. Estimation of the Molecular Weight of the Higher Molecular Weight Fraction. The molecular weight of the higher molecular weight fractions was estimated with the calibration curve (Figure 11) that shows the relationship between the common logarithm and the ratio $V_{e} / V_{0}$ between the elution volume and the void volume. Table 2 shows the values $V_{e} / V_{0}$ for the higher molecular weight fractions at varying reaction times and temperatures.

The estimated molecular weight was almost comparable with the position of the first peak on the chromatograms of Figures 7-9. The samples from the reaction of BocGly-L-Asp for $24 \mathrm{~h}$ gave the following values: 4400,7000 , and $4600 \mathrm{Da}$ for 110,120 , and $130^{\circ} \mathrm{C}$, respectively. A proper combination of the reaction conditions gave the highest 


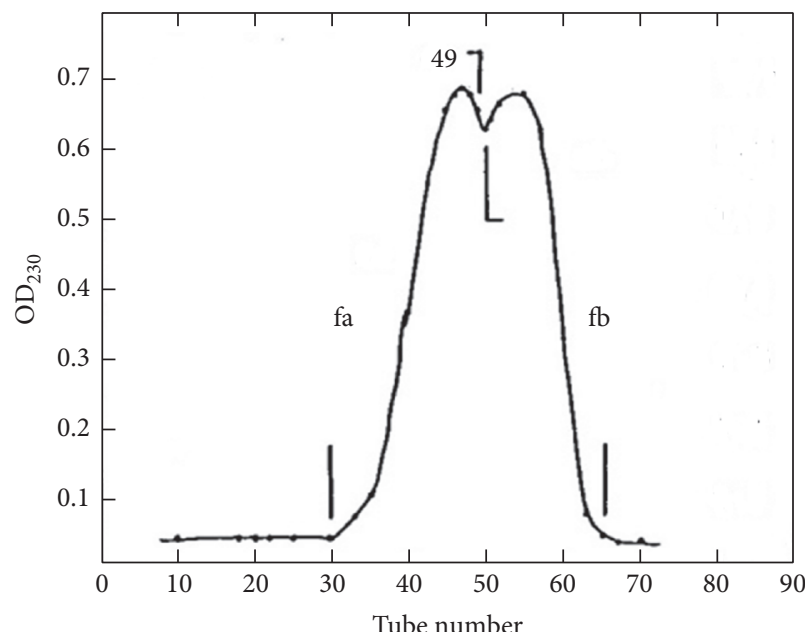

(a)

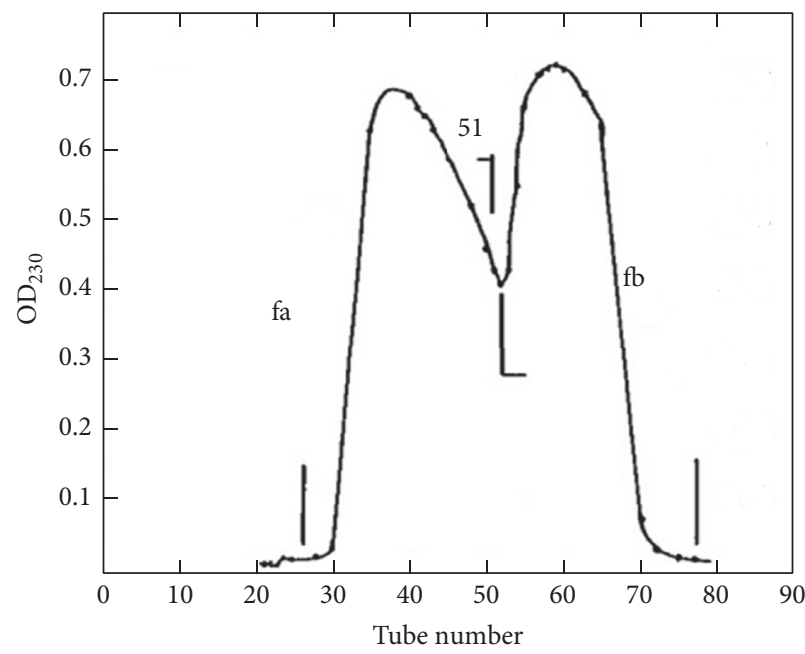

(c)

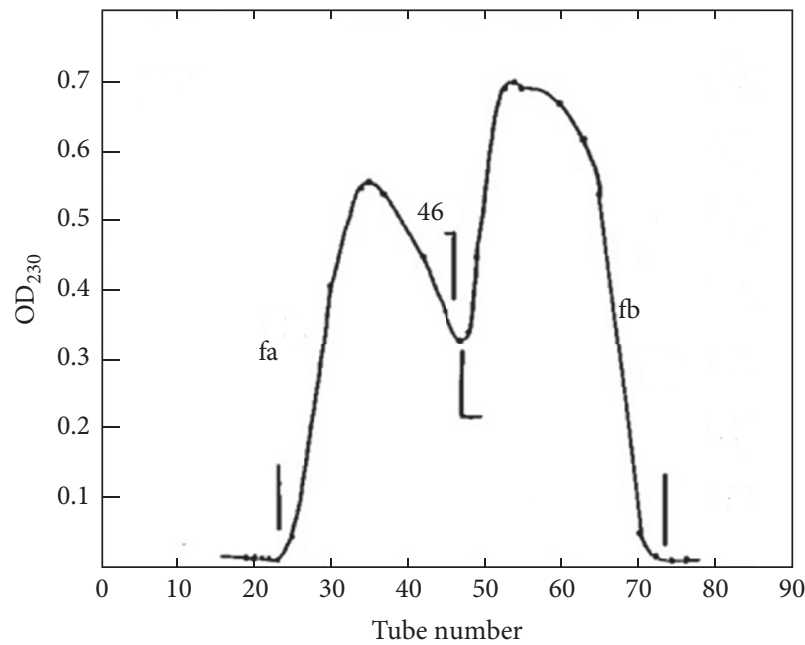

(e)

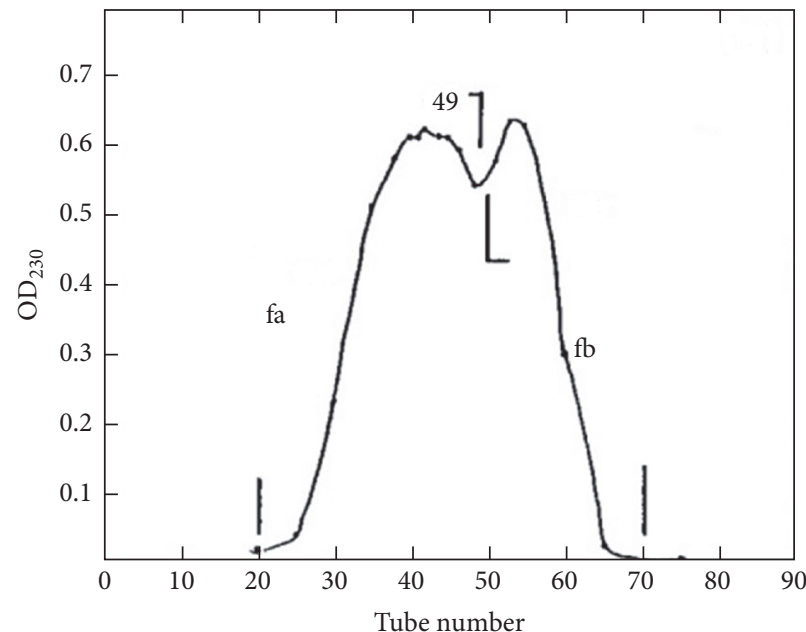

(b)

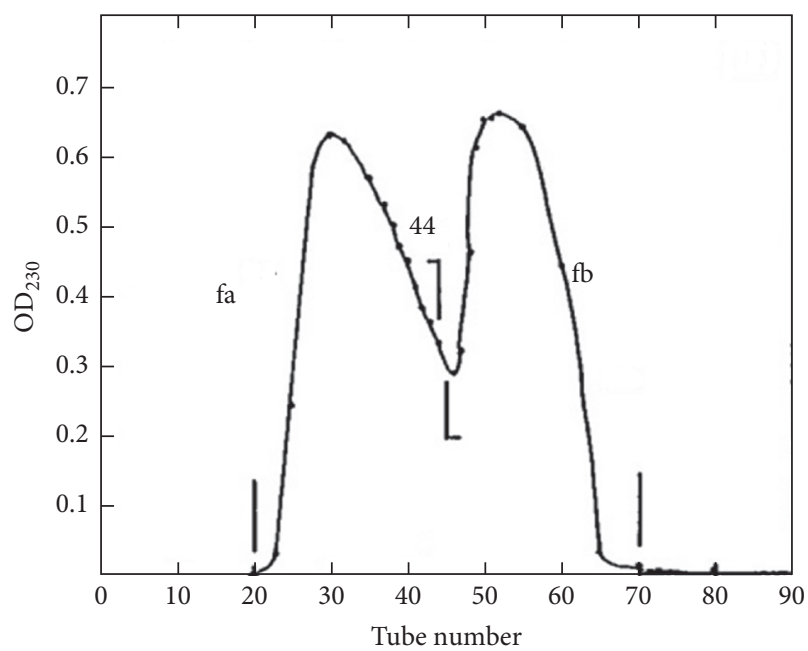

(d)

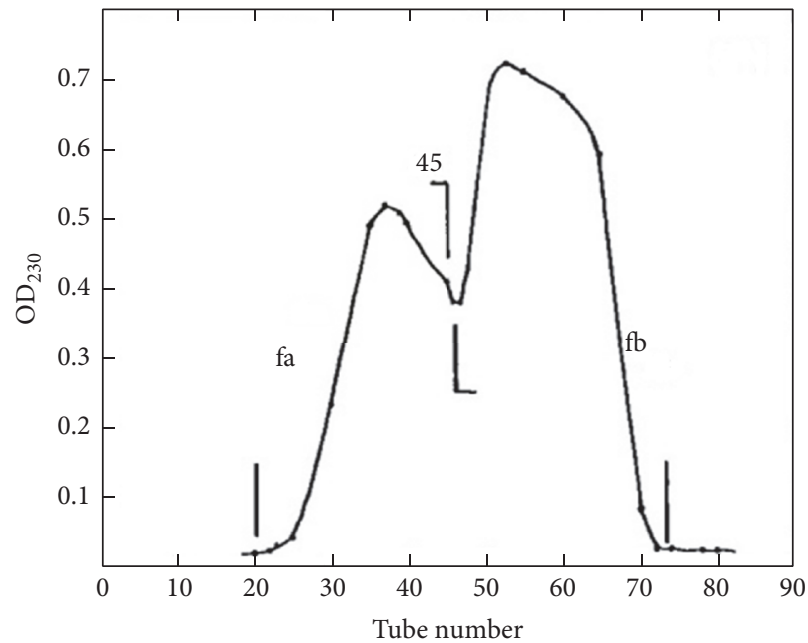

(f)

Figure 7: Gel permeation chromatograms of the reaction mixtures of Boc-Gly-L-Asp at $130^{\circ} \mathrm{C}$ for varying reaction times: (a) $1 \mathrm{~h}$; (b) $2 \mathrm{~h}$; (c) $4 \mathrm{~h}$; (d) $8 \mathrm{~h}$; (e) $16 \mathrm{~h}$; and (f) $24 \mathrm{~h}$. Solid phase: Sephadex G-25F. Eluate: $0.5 \mathrm{M}$ acetic acid. Volume per test tube: $3 \mathrm{~mL}$. fa: ninhydrin-negative, higher molecular weight fractions; fb: ninhydrin-positive lower molecular weight fractions. 


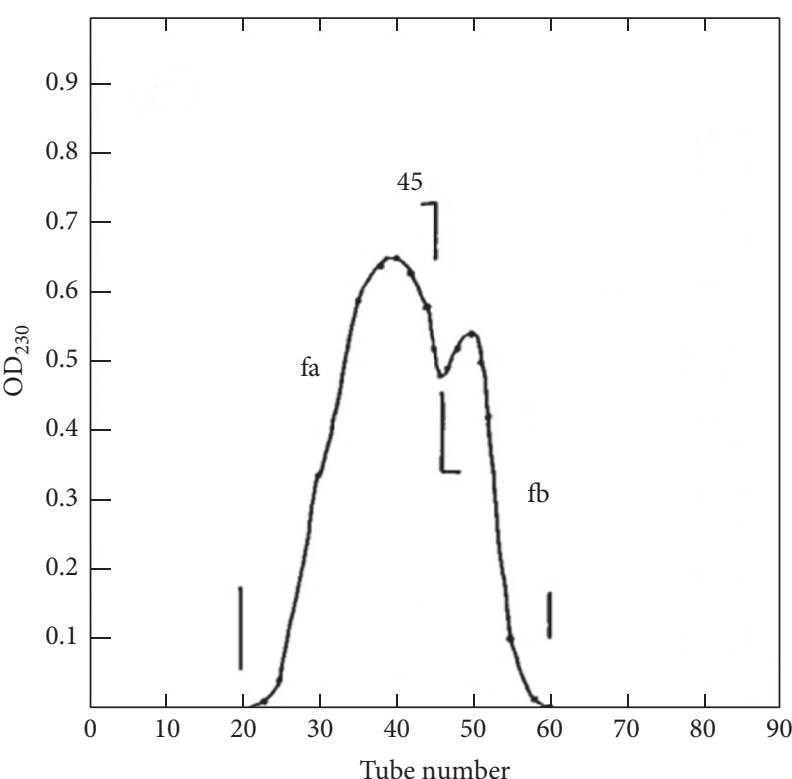

(a)

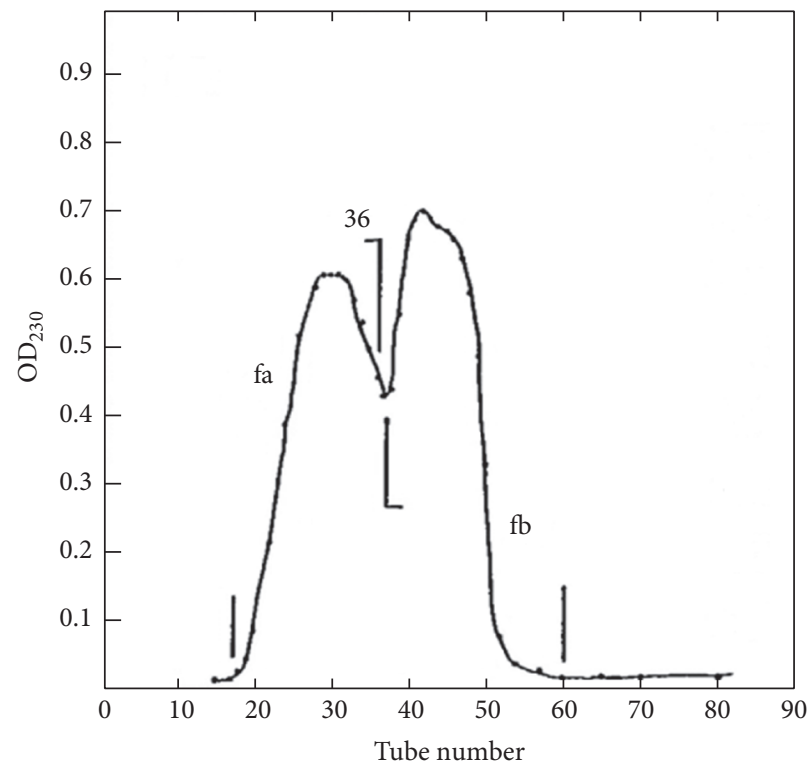

(c)

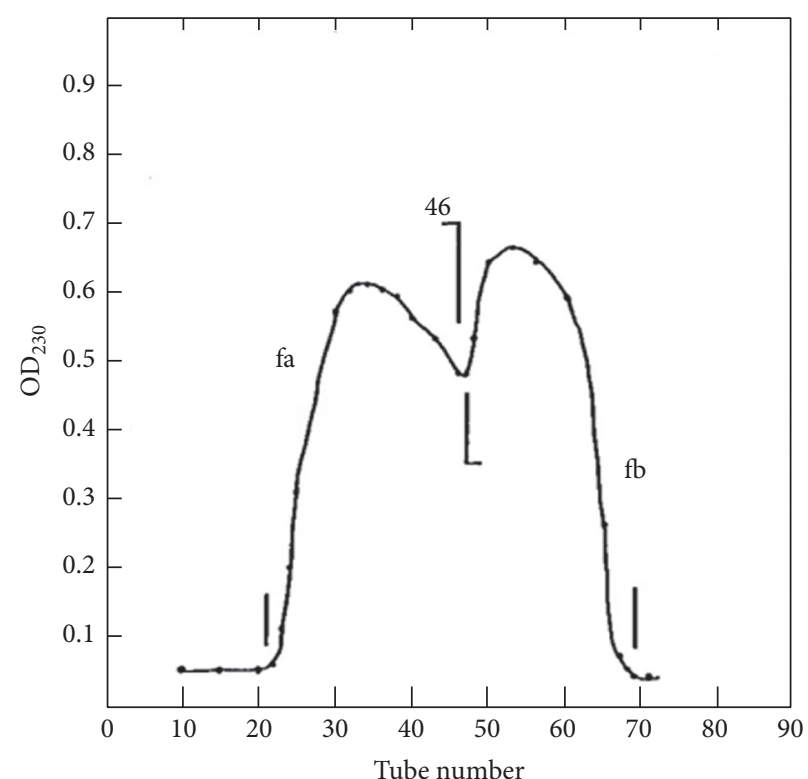

(b)

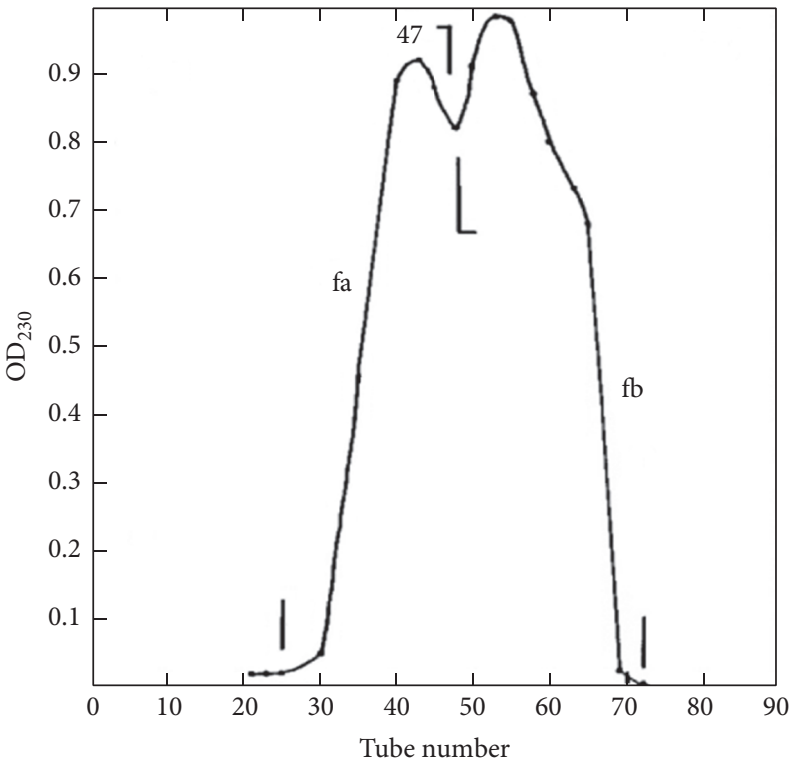

(d)

FiguRE 8: Gel permeation chromatograms of the reaction mixtures of Boc-Gly-L-Asp (5a) at varying temperatures and times: (a) $110^{\circ} \mathrm{C}, 24 \mathrm{~h}$; (b) $120^{\circ} \mathrm{C}, 24 \mathrm{~h}$; (c) $150^{\circ} \mathrm{C}, 2 \mathrm{~h}$; and (d) $170^{\circ} \mathrm{C}, 2 \mathrm{~h}$. Solid phase: Sephadex G-25F. Eluate: $0.5 \mathrm{M}$ acetic acid. Volume per a test tube: $3 \mathrm{~mL}$. fa: ninhydrin-negative, higher molecular weight fractions; fb: ninhydrin-positive lower molecular weight fractions.

molecular weight, and a temperature that was too high gave a lower molecular weight because of enhanced degradation. The effect of reaction time at the same temperature could be seen in detail in the reactions at $130^{\circ} \mathrm{C}$. The shorter reaction times gave a lower molecular weight but it was higher with reaction time (2800, 4100, and 6900 for 1,2 , and $4 \mathrm{~h}$, resp.); the medium reaction time gave the highest molecular weight: 7800 for $8 \mathrm{~h}$; the longer reaction time gave a lower molecular weight (5400 and $4600 \mathrm{Da}$ for 16 and $24 \mathrm{~h}$, resp.) again. The other substrates resulted in a similar tendency as for substrate $5 a$.
3.5. Amino Acid Composition and D/L Ratio of the Residue in the Higher Molecular Weight Fraction. The amino acid composition and the $\mathrm{D} / \mathrm{L}$ ratio in the acid-hydrolysate of the higher molecular weight fractions are listed in Table 3.

The amino acid compositions were almost even at the level of the theoretical value in the hydrolysates obtained with the higher molecular weight fractions of the Bocdipeptides at lower temperatures and for shorter reaction times. However, the hydrolysates of the obtained higher molecular weight fractions at the higher temperature and longer reaction times gave higher compositions for amino 


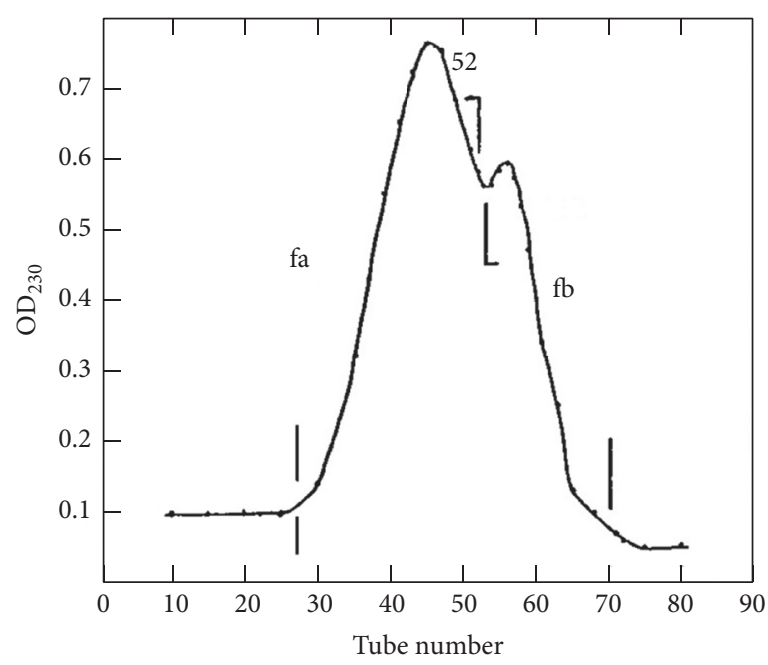

(a)

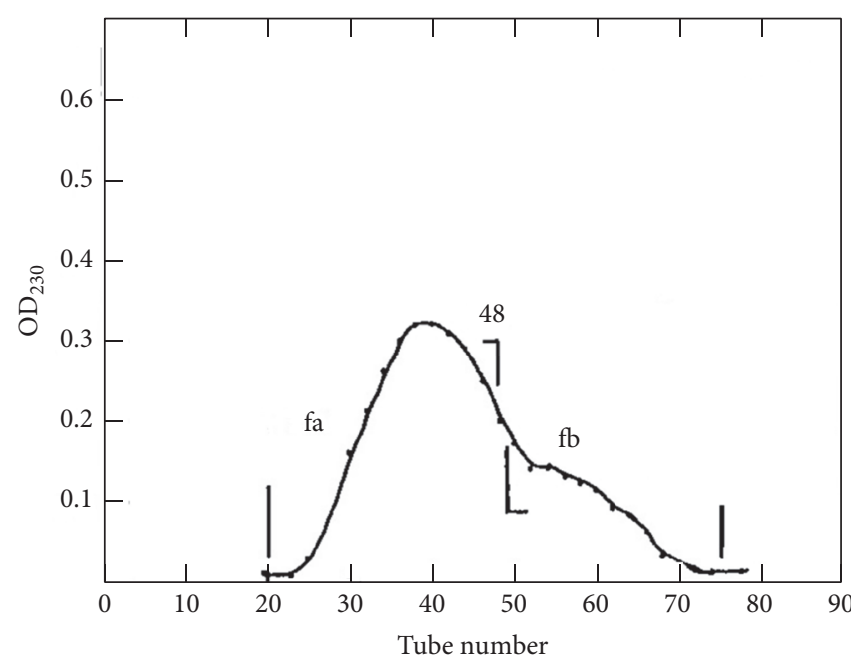

(b)

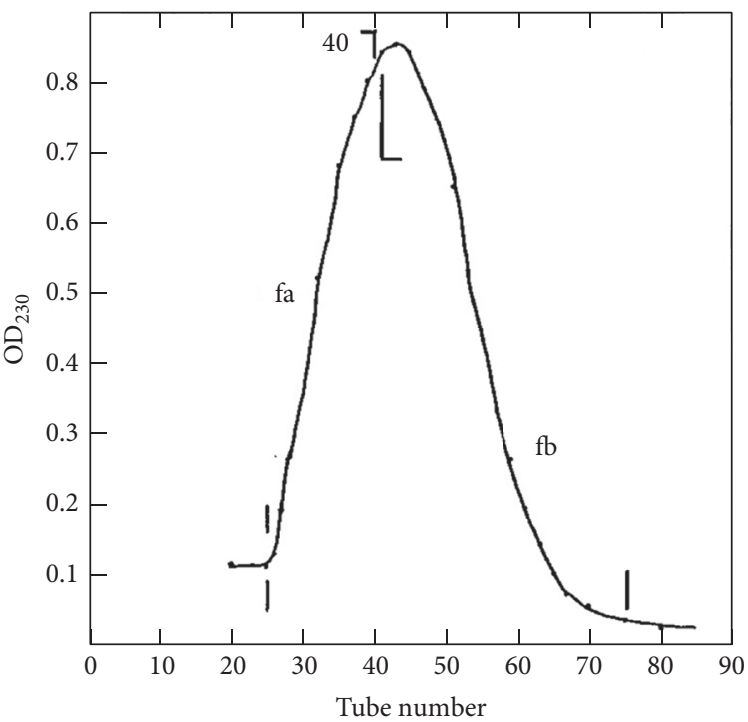

(c)

FIGURE 9: Gel permeation chromatograms of the reaction mixtures of peptide derivatives under different conditions. (a) Boc-L-Ala-L-Asp, $130^{\circ} \mathrm{C}, 1 \mathrm{~h}$; (b) Boc-L-Val-L-Asp, $130^{\circ} \mathrm{C}, 2 \mathrm{~h}$; and (c) $120^{\circ} \mathrm{C}, 4 \mathrm{~h}$. Solid phase: Sephadex G-25F. Eluate: $0.5 \mathrm{M}$ acetic acid. Volume per a test tube: $3 \mathrm{~mL}$. fa: ninhydrin-negative, higher molecular weight fractions; fb: ninhydrin-positive lower molecular weight fractions.

acids other than aspartic acid, because the latter is more labile to decomposition at higher temperatures than other amino acids. The hydrolysates of the product formed a tripeptide derivative: Boc-Gly-Gly-L-Asp gave Gly and Asp with the ratio of $2: 1$. The amino acid recovery after hydrolysis was from $76 \%$ to almost the quantitative amount.

Regarding the $\mathrm{D} / \mathrm{L}$ ratio, the molar ratio of the $\mathrm{D}$-isomer to L-isomer of aspartic acid was higher in the hydrolysates of the products with the higher temperature and the longer reaction. The $\mathrm{D} / \mathrm{L}$ ratio from the products was 0.142 at $130^{\circ} \mathrm{C}$ for $24 \mathrm{~h}, 0.189$ at $150^{\circ} \mathrm{C}$ for $2 \mathrm{~h}$, and 0.596 at $170^{\circ} \mathrm{C}$ for $2 \mathrm{~h}$. The $\mathrm{D} / \mathrm{L}$ ratios of other amino acids were lower than that for aspartic acid. The existence of D-isomers may be explained by racemization [22] of $\mathrm{L}$-aspartic acid or epimerization of L-aspartyl residues in the polypeptides. L-Aspartic acid undergoes the fastest racemization and epimerization of the all proteinous amino acids, because particularly aspartic residue forms imide structure which fosters the epimerization [23-26]. However, if some better reaction conditions were selected, such racemization and epimerization could be minimized to be lower than $10 \%$. In contrast, racemization and epimerization of Asp residue might proceed in the range of $1 \%$ to $2 \%$ during $8 \mathrm{~h}$ hydrolysis at $110^{\circ} \mathrm{C}$. The actual D/L ratio in the polypeptides must be $1 \%$ to $2 \%$ lower than the results in Table 3.

3.6. Analysis of the Lower Molecular Weight Fractions. HPLC results of the heating reaction mixtures of Boc-dipeptides $(\mathbf{5 a}-\mathbf{c})$ gave two peaks on the chromatogram by means of G-3000PM, whereas the Boc-tripeptide (Boc-Gly-Gly-L-Asp: 


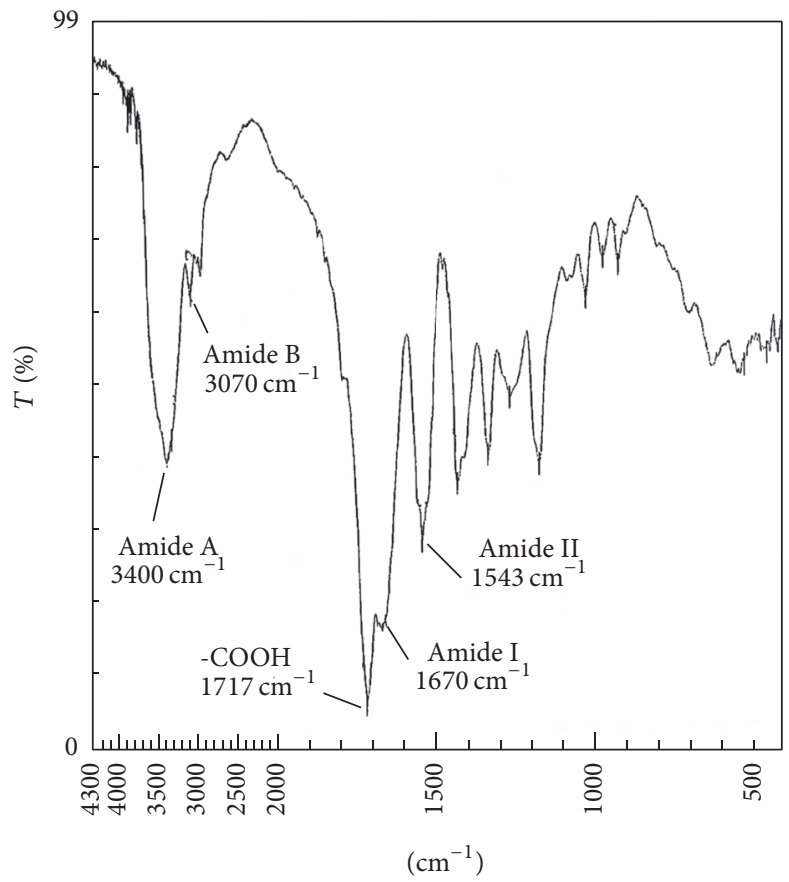

FIGURE 10: IR spectrum of the higher molecular weight fraction of the reaction mixture obtained from Boc-Gly-L-Asp at $130^{\circ} \mathrm{C}$ for $8 \mathrm{~h}$.

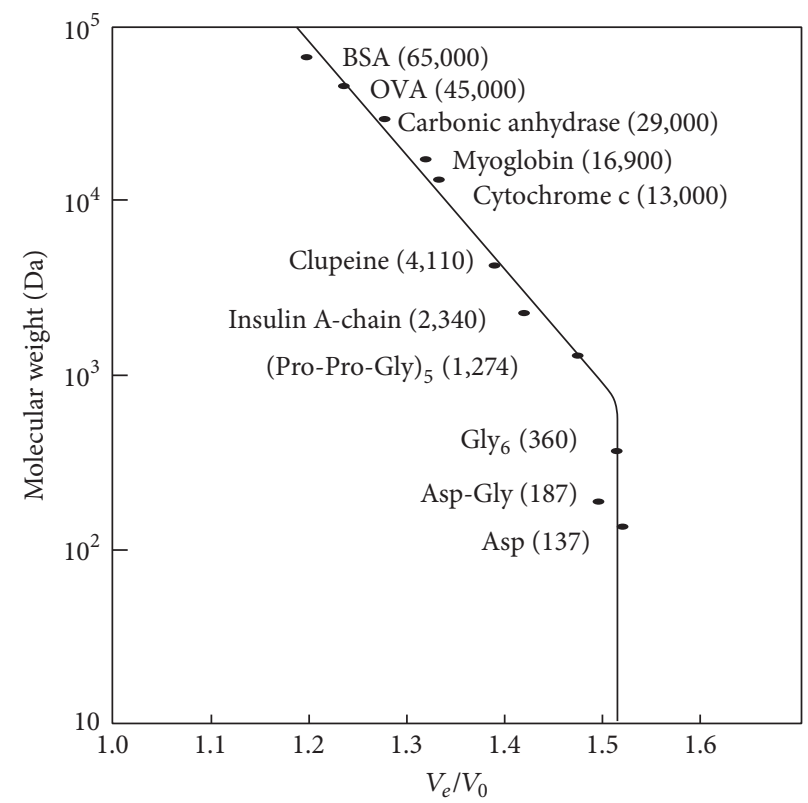

FIGURE 11: Calibration curve of the molecular weight of peptides using HPLC with a TSK-GEL G-3000PW $(300 \mathrm{~mm} \times 7.5 \mathrm{~mm}$ i.d.). Eluent: $0.1 \mathrm{M}$ sodium phosphate buffer, $\mathrm{pH}$ 6.9; flow rate: $0.7 \mathrm{~mL} / \mathrm{min}$; detection: $\mathrm{UV} 230 \mathrm{~nm}$. $V_{e}$ : volume $(\mathrm{mL})$ of elution for each sample; $V_{0}$ : elution volume of blue dextran as void volume $(\mathrm{mL})$.

5d) gave only one (Figure 12: (a) Boc-L-Val-L-Asp (5c) and (b) Boc-Gly-Gly-L-Asp (5d)).

Chromatogram (a) gave only one peak, but (b) gave two peaks, in which the longer retention time peak was caused by the lower molecular weight products. The IR spectrum (Figure 12) of the lower molecular weight fraction from
Boc-L-Val-L-Asp showed absorption for the groups of Amide I $\left(1663 \mathrm{~cm}^{-1}\right)$ and $-\mathrm{COOH}\left(1717 \mathrm{~cm}^{-1}\right)$ or imide and the IR spectrum of Boc-Gly-Gly-L-Asp showed Amide II, as well as $\mathrm{COOH}$, and Amide I $\left(1545,1717\right.$, and $1663 \mathrm{~cm}^{-1}$, resp.). As the lower molecular weight fraction from the reaction mixture of Boc-L-Val-L-Asp (5c) has - $\mathrm{COOH}$ and amide groups but 
TABLE 2: Estimated molecular weight of the higher molecular weight fraction.

\begin{tabular}{|c|c|c|c|c|c|}
\hline Substrate & Temperature $/{ }^{\circ} \mathrm{C}$ & Reaction time/h & $V_{e} / V_{0}^{\mathrm{a}}$ & Molecular weight/Da & Number $(n)$ of residues (AA-Asp) $n$ \\
\hline \multirow{10}{*}{ Boc-Gly-L-Asap (5a) } & 110 & 24 & 1.395 & 4400 & 26 \\
\hline & 120 & 24 & 1.362 & 7000 & 41 \\
\hline & 130 & 1 & 1.423 & 2800 & 16 \\
\hline & 130 & 2 & 1.397 & 4100 & 24 \\
\hline & 130 & 4 & 1.363 & 6900 & 40 \\
\hline & 130 & 8 & 1.354 & 7800 & 45 \\
\hline & 130 & 16 & 1.381 & 5400 & 31 \\
\hline & 130 & 24 & 1.389 & 4600 & 23 \\
\hline & 150 & 2 & 1.430 & 2500 & 15 \\
\hline & 170 & 2 & 1.468 & 1400 & 8 \\
\hline \multirow{3}{*}{ Boc-L-Ala-L-Asp (5b) } & 130 & 1 & 1.466 & 1500 & 8 \\
\hline & 130 & $2^{\mathrm{b}}$ & 1.421 & 2900 & 16 \\
\hline & 130 & $4^{\mathrm{b}}$ & 1.382 & 5200 & 28 \\
\hline \multirow{3}{*}{ Boc-L-Val-L-Asp (5c) } & 120 & $4^{\mathrm{b}}$ & 1.447 & 2000 & 9 \\
\hline & 130 & 2 & 1.441 & 2200 & 10 \\
\hline & 130 & $4^{\mathrm{b}}$ & 1.393 & 4200 & 20 \\
\hline \multirow{4}{*}{ Boc-Gly-Gly-L-Asp (5d) } & 120 & 4 & 1.354 & 7800 & 34 \\
\hline & 120 & $4^{\mathrm{b}}$ & 1.404 & 3700 & 16 \\
\hline & 130 & $2^{\mathrm{b}}$ & 1.402 & 4000 & 17 \\
\hline & 130 & $4^{\mathrm{b}}$ & 1.385 & 5000 & 21 \\
\hline
\end{tabular}

${ }^{\mathrm{a}} V_{e}$ : volume of elution; $V_{0}$ : void volume; ${ }^{\mathrm{b}}$ intact reaction mixture without gel filtration.

TABLE 3: Amino acid composition and D/L ratio of hydrolysates of the higher molecular weight fractions.

\begin{tabular}{|c|c|c|c|c|c|c|c|c|}
\hline \multirow{2}{*}{ Substrate } & \multirow{2}{*}{ Temperature $/{ }^{\circ} \mathrm{C}$} & \multirow{2}{*}{ Reaction time/h } & \multirow{2}{*}{$\mathrm{Mw} / \mathrm{Da}$} & \multicolumn{2}{|c|}{ AA composition } & \multicolumn{2}{|c|}{$\mathrm{D} / \mathrm{L}$ ratio } & \multirow{2}{*}{ AA recovery $/ \%$} \\
\hline & & & & AA & Asp & AA & Asp & \\
\hline \multirow{10}{*}{ Boc-Gly-L-Asp (5a) } & 110 & 24 & 4400 & 1.11 & 1.00 & - & 0.064 & 95 \\
\hline & 120 & 24 & 7000 & 0.98 & 1.00 & - & 0.061 & 104 \\
\hline & 130 & 1 & 2800 & 1.10 & 1.00 & - & 0.058 & 87 \\
\hline & 130 & 2 & 4100 & 1.08 & 1.00 & - & 0.072 & 76 \\
\hline & 130 & 4 & 6900 & 1.10 & 1.00 & - & 0.087 & 93 \\
\hline & 130 & 8 & 7800 & 1.10 & 1.00 & - & 0.098 & 88 \\
\hline & 130 & 16 & 5400 & 1.12 & 1.00 & - & 0.122 & 84 \\
\hline & 130 & 24 & 4600 & 1.09 & 1.00 & - & 0.142 & 83 \\
\hline & 150 & 2 & 2500 & 1.11 & 1.00 & - & 0.189 & 100 \\
\hline & 170 & 2 & 1400 & 1.13 & 1.00 & - & 0.596 & 100 \\
\hline Boc-L-Ala-L-Asp (5b) & 130 & 1 & 1500 & 1.00 & 1.00 & 0.042 & 0.067 & 88 \\
\hline Boc-L-Val-L-Asp (5c) & 130 & 2 & 2200 & 0.94 & 1.00 & 0.017 & 0.099 & 78 \\
\hline Boc-Gly-Gly-L-Asp (5d) & 120 & 4 & 7800 & 1.95 & 1.00 & - & 0.059 & 102 \\
\hline
\end{tabular}

not the linear peptide, the fractions are suggested to include the structure of 2,5-diketopiperazine (DKP) [27] or a kind of imide [20] structure.

3.7. Postulated Mechanism of the Thermal Reaction of BocPeptides. From the many features of the thermal reactions of substrate Boc-peptides and the products described above, we propose the reaction mechanism of the thermal reaction depicted in Figure 14.

There might be three reaction intermediates, 6, 7, and $\mathbf{8}$, from substrates $\mathbf{5 b}-\mathbf{d}$ to polypeptide $\mathbf{9}$. Intermediate $\mathbf{6}$ may be produced by releasing 2 -butene and carbon dioxide first. Intermediate 7 may be produced by releasing water first. Intermediate $\mathbf{8}$ may be produced from intermediates $\mathbf{6}$ and 7 


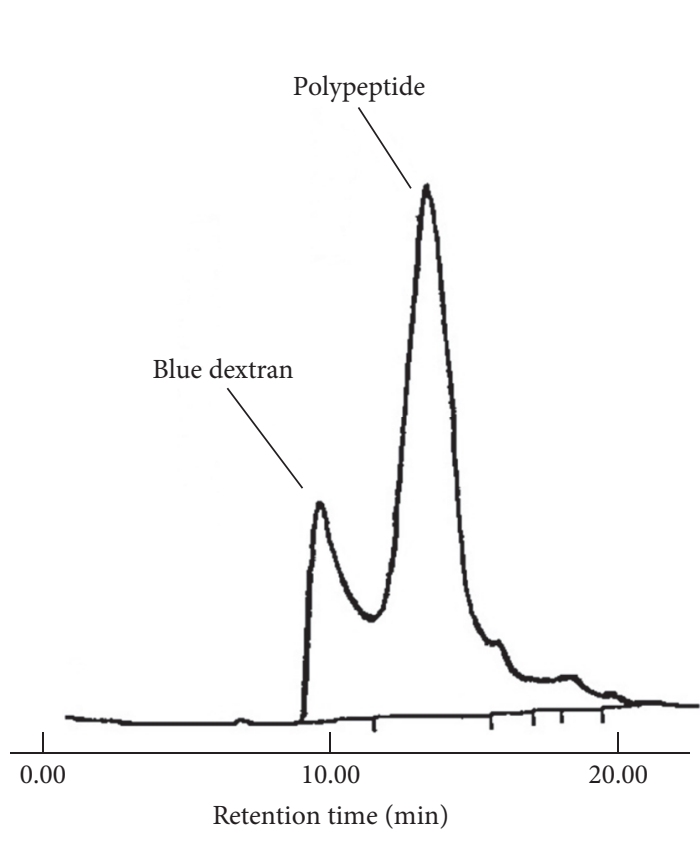

(a)

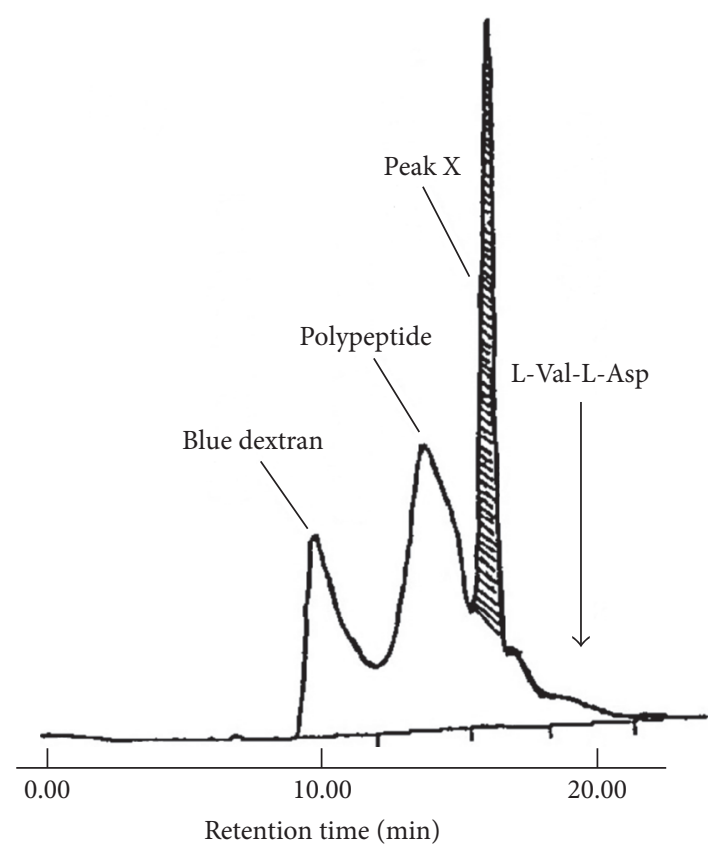

(b)

FIGURE 12: Chromatograms of the crude products obtained from Boc-Gly-Gly-L-Asp (a) at $120^{\circ} \mathrm{C}$ for $4 \mathrm{~h}$ and Boc-L-Val-L-Asp (b) at $130^{\circ} \mathrm{C}$ for $2 \mathrm{~h}$ in the heating reactions using an HPLC equipped with a TSK-GEL G-3000PW (300 $\mathrm{mm} \times 7.5 \mathrm{~mm}$ i.d.). Eluent: $0.1 \mathrm{M}$ sodium phosphate buffer, pH 6.9; flow rate: $0.7 \mathrm{~mL} / \mathrm{min}$; detection: UV $230 \mathrm{~nm}$.

or from substrate $\mathbf{5 a - d}$ directly. The actual reaction mixture can include the three intermediates $(6,7$, and 8$)$, because the analysis of the gases directly injected from thermal reaction to the mass spectrometer indicated that the three gases continuously evolved at the same temperature, although the order is $\mathrm{CO}_{2}$ plus water and then 2-butene (Figures 3 and 4). Therefore, intermediates 6 and 8 can yield polypeptide 9. Intermediate 6 would directly dehydrate between an amino group and a carboxy group to yield a peptide bond. Intermediate 8 would be attacked by an amino group to open its anhydride group and form two kinds of peptide bond that are linked using the $\alpha$ - and $\beta$-carboxy groups; and then complete dehydration makes imide (10) bonds in polypeptides (9).

A part of dipeptide derivatives $(\mathbf{5 a}-\mathbf{c})$ form six-membered ring compounds (2,5-diketopiperazine: DKP (11) [27]), which may not polymerize anymore. The existence of DKP in the lower molecular weight fractions can be supported by the IR spectrum (B) (Figure 13), which has the absorbance of DKP $\left(1663 \mathrm{~cm}^{-1}\right)$ and carboxyl group of $-\mathrm{COOH}\left(1710 \mathrm{~cm}^{-1}\right)$. Another estimated structure showing absorbance at $1710 \mathrm{~cm}^{-1}$ may be a tetrapeptide imide structure like compound $\mathbf{1 0}(n=1 ; q=1)$, which could form by coupling of two dipeptides, for instance, Val-Asp from $\mathbf{5 c}$ in Figure 14. However, the anhydride structure of compound 10 would have partly opened by hydrolysis during chromatography. If the tetrapeptide imide structure cyclized from head to tail, the resulting product would have two fivemembered cyclic imides and a twelve-membered cyclic

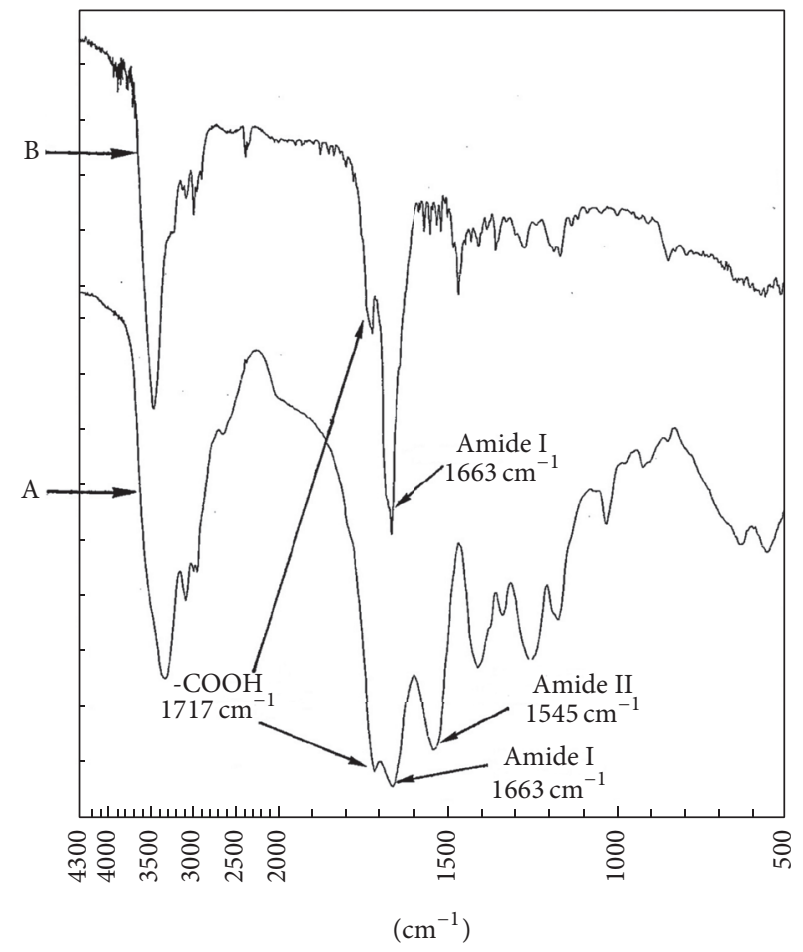

FIGURE 13: IR spectra of the lower molecular weight fractions obtained from Boc-Gly-Gly-L-Asp (A) at $120^{\circ} \mathrm{C}$ for $4 \mathrm{~h}$ and Boc-LVal-L-Asp (B) at $130^{\circ} \mathrm{C}$ for $2 \mathrm{~h}$ in the reaction heating reactions.

peptide. Therefore, the lower molecular weight fraction may include DKP and the tetrapeptide imide structure. Further 

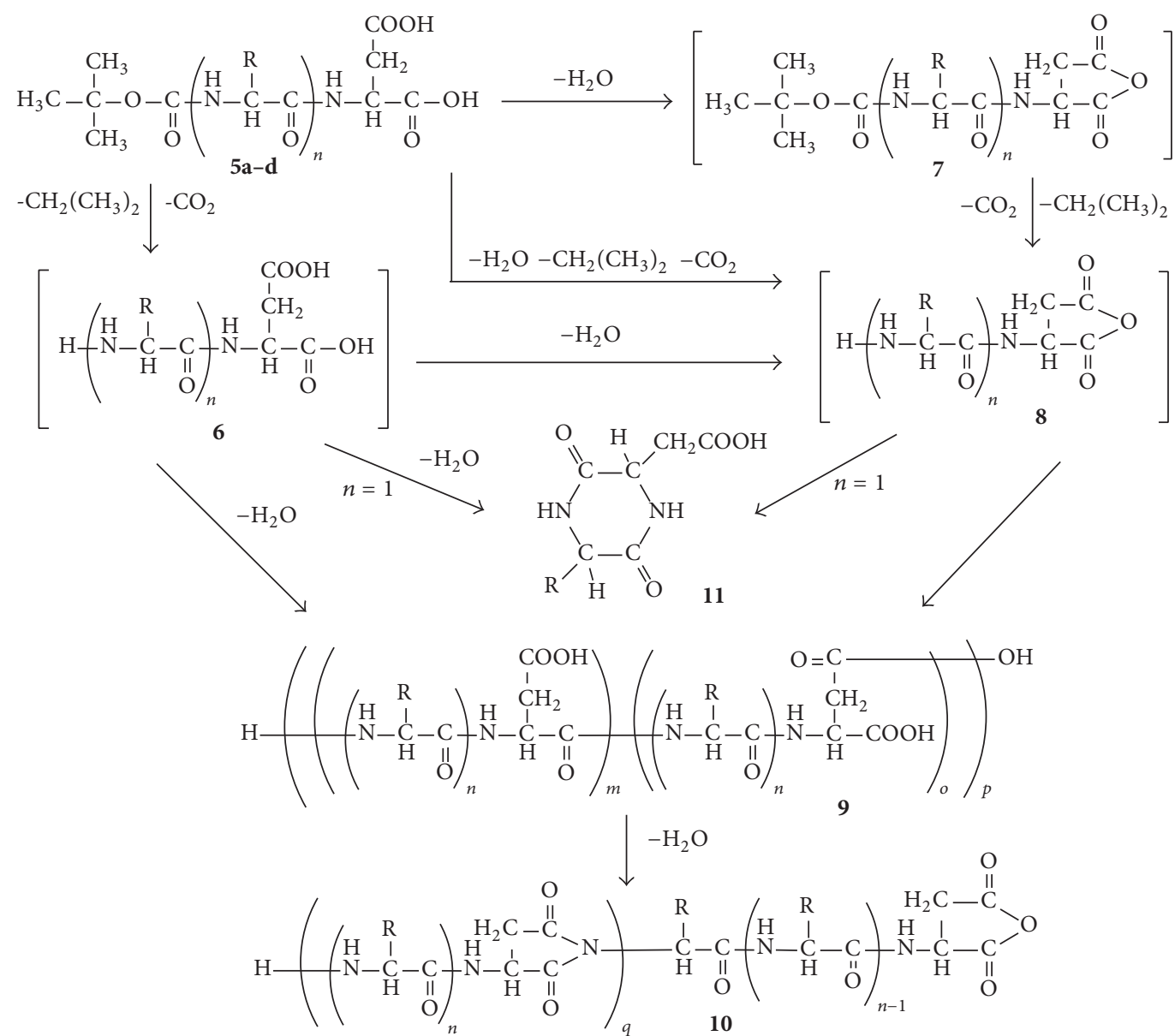

Figure 14: Postulated mechanism of the thermal reaction of Boc-peptides (5a-d). $n=1$ for $\mathbf{5 a}-\mathbf{c} ; n=2$ for $\mathbf{5 d}$. $m, n, o, p$, and $q$ : natural number $(0,1,2,3, \ldots)$.
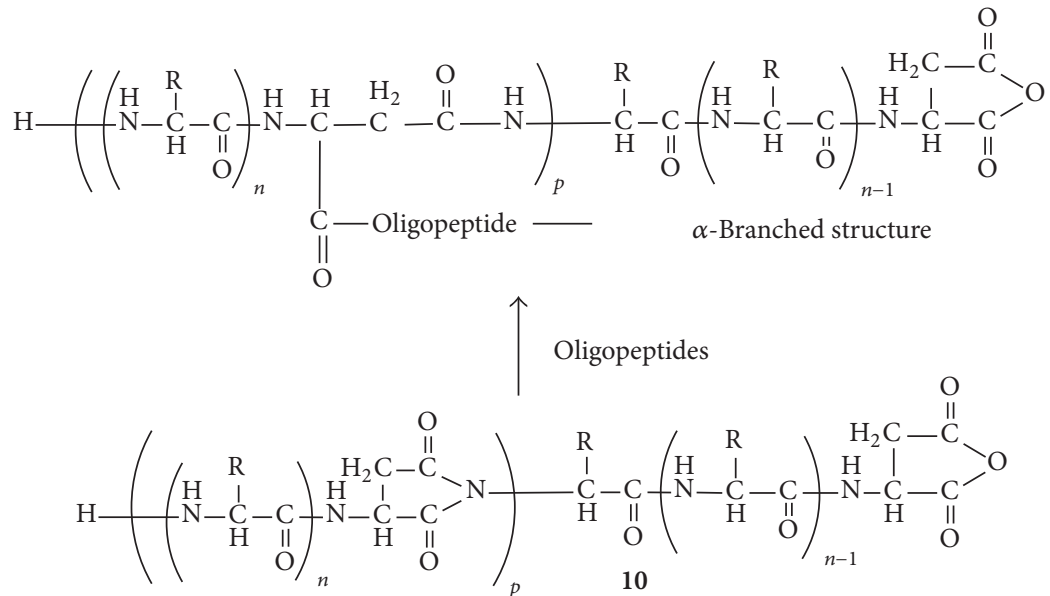

Oligopeptides

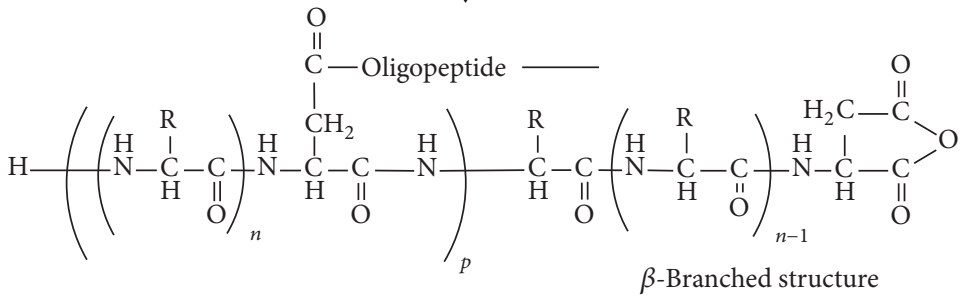

FIGURE 15: Postulated branched structures from Boc-peptides upon heating. $n=1$ for $\mathbf{5 a}-\mathbf{c} ; n=2$ for $\mathbf{5 d}$. $n$ and $p$ : natural number $(1,2,3, \ldots)$. 
study of isolation of these compounds will give proof of the hypothesis.

The results in this paper reveal that the heating reactions of N-Boc-oligopeptides gave higher molecular peptides, which have almost the same amino acid compositions as their starting substrates.

The results suggest that the polypeptide products have a sequential structure but it is not established clearly. There may be some cases to yield branched polypeptides, which can be made during the reactions of the imide structure with the deprotected oligopeptides as shown in Figure 15. Since the chemical structure is very complexed, further research may be needed to clarify the details in the future research.

\section{Conclusions}

This investigation has demonstrated the first simple successive heating synthesis of copolypeptides by using peptide derivatives. In the thermal reactions, Boc-peptides melted, released a protecting group, and dehydrated to polypeptides. The mechanism was supported by thermal analysis accompanied by mass spectrometry. The holding amino acid residues in the polyamino acid structure were supported by amino acid analysis. The D/L ratio was suppressed to be below $10 \%$ at lower temperatures. These results suggested that the thermal reaction using Boc-peptides might be useful for producing sequential polypeptides. The sequential structure that is not proven should be clarified in the future research.

\section{Disclosure}

Takafumi Yamada is currently affiliated Center for Basic Technology Research, Tokyo Metropolitan Institute of Medical Science, Setagaya-ku, Tokyo 156-8506, Japan.

\section{Conflicts of Interest}

The authors declare that they have no conflicts of interest.

\section{Acknowledgments}

The authors thank the late professor emeritus Kaoru Harada of the University of Tsukuba for fruitful discussions.

\section{References}

[1] J. H. Johns, Chemistry and Biochemistry of Amino Acids, Peptides, vol. 4, Marcel Decker Inc., New York, NY, USA, 1977.

[2] Y. Imanishi, "Polymerization Of $\alpha$-amino acid $N$ carboxyanhydride in the presence of preformed poly $(\alpha$-Amino Acid)-from chain effect to stereoselective polymerization," Pure and Applied Chemistry, vol. 53, no. 3, pp. 715-727, 1981.

[3] H. R. Kricheldorf, "Polypeptides and 100 years of chemistry of $\alpha$-amino acid N-carboxyanhydrides," Angewandte Chemie, vol. 45, no. 35, pp. 5752-5784, 2006.

[4] P. C. Brown and L. E. Glynn, "The antigenicity of sequential polypeptides. II. The antigenicity of some sequential polymers including several related to collagen," Immunology, vol. 25, no. 2, pp. 251-260, 1973.
[5] J. Ramachandran, A. Berger, and E. Katchalski, "Synthesis and physicochemical properties in aqueous solution of the sequential polypeptide poly(Tyr-Ala-Glu)," Biopolymers, vol. 10, no. 10, pp. 1829-1851, 1971.

[6] R. S. Rapaka and D. W. Urry, "Coacervation of sequential polypeptide models of tropoelastin. Synthesis of H-(ValAla-Pro-Gly)n-Val-OMe and H-(Val-Pro-Gly-Gly)n-Val-OMe," International Journal of Peptide and Protein Research, vol. 11, no. 2, pp. 97-108, 1978.

[7] R. S. Rapaka, K. Okamoto, and D. W. Urry, "Non-elastomeric polypeptide models of elastin. Synthesis of polyhexapeptides and a cross-linked polyhexapeptide," International Journal of Peptide and Protein Research, vol. 11, no. 2, pp. 109-127, 1978.

[8] S. Sakakibara, Y. Kishida, Y. Kikuchi, R. Sakai, and K. Kakiuchi, "Synthesis of poly-(L-prolyl-L-prolylglycyl) of defined molecular weights," Bulletin of the Chemical Society of Japan, vol. 41, no. 5, pp. 1273-1273, 1968.

[9] H. Leuchs, "Ueber die Glycin-carbonsäure," Berichte der Deutschen Chemischen Gesellschaft, vol. 39, no. 1, pp. 857-861, 1906.

[10] R. B. Woodward and C. H. Schramm, "Synthesis of protein analogs," Journal of the American Chemical Society, vol. 69, no. 6, pp. 1551-1552, 1947.

[11] A. B. Hughes, Amino Acids, Peptides and Proteins in Organic Chemistry, Building Blocks, Catalysis and Coupling Chemistry (Amino Acids, Peptides and Proteins in Organic Chemistry $(\mathrm{VCH})$ ), Wiley \& Sons, New York, NY, USA, 2011.

[12] Humana Press, "Peptide Synthesis and Applications," in Methods in Molecular Biology, K. J. Jensen, A. P. Tofteng, and S. L. Pedersen, Eds., Springer, New York, NY, USA, 2nd edition, 2013.

[13] A. Vegotsky, K. Harada, and S. W. Fox, "The characterization of polyaspartic acid and some related compounds," Journal of the American Chemical Society, vol. 80, no. 13, pp. 3361-3366, 1958.

[14] J. Kovacs, H. N. Kovacs, I. Könyves, J. Császár, T. Vajda, and H. Mix, "Chemical studies of polyaspartic acids," Journal of Organic Chemistry, vol. 26, no. 4, pp. 1084-1091, 1961.

[15] T. Munegumi, Y.-Q. Meng, and K. Harada, “Thermal Syntheses of Polypeptides from N-Boc-amino acid (Aspartic acid, $\beta$ aminoglutaric acid) anhydrides," Chemistry Letters, vol. 17, no. 10, pp. 1643-1646, 1988.

[16] T. Munegumi and K. Harada, "Synthesis of polypeptides from amino acid derivatives melted upon heating," Peptide Chemistry 1990, pp. 75-78, 1991.

[17] W. Parr and P. Howard, "Separation of amino acid enantiomers by gas chromatography with an optically active stationary phase (N-TFA-L-valyl-L-leucine cyclohexyl ester)," Chromatographia, vol. 4, no. 4, pp. 162-166, 1971.

[18] H. Frank, G. J. Nicholson, and E. Bayer, "Rapid gas chromatographic separation of amino acid enantiomers with a novel chiral stationary phase," Journal of Chromatographic Science, vol. 15, no. 5, pp. 174-176, 1977.

[19] J. S. Davis, Amino Acid and Peptides, Chapman and Hall, London, UK, 1985.

[20] T. Munegumi, Y. Qing Meng, and K. Harada, "Polypeptide formation by heating $N$-t-butyloxycarbonyl acidic amino acid derivatives," Asian Journal of Chemistry, vol. 26, no. 15, pp. 47164722, 2014.

[21] T. Munegumi, K. Akao, Y. Kawatu, T. Yamada, and K. Harada, "Heating reactions of $\mathrm{N}$-t-Butyloxycarbonyl-Asparagine and related compounds," Asian Journal of Chemistry, vol. 26, no. 19, pp. 6541-6548, 2014. 
[22] G. G. Smith and B. S. De Sol, "Racemization of amino acids in dipeptides shows $\mathrm{COOH}>\mathrm{NH}_{2}$ for non-sterically hindered residues," Science, vol. 207, no. 4432, pp. 765-767, 1980.

[23] K. Harada, M. Matsuyama, and E. Kokufuta, "The aqueous thermal polycondensation of asparagine and isoasparagine and the structure of polyaspartic acid," Polymer Bulletin, vol. 1, no. 3, pp. 177-180, 1978.

[24] J. L. Radkiewicz, H. Zipse, S. Clarke, and K. N. Houk, "Accelerated racemization of aspartic acid and asparagine residues via succinimide intermediates: an ab initio theoretical exploration of mechanism," Journal of the American Chemical Society, vol. 118, no. 38, pp. 9148-9155, 1996.

[25] J. L. Radkiewicz, H. Zipse, S. Clarke, and K. N. Houk, "Neighboring side chain effects on asparaginyl and aspartyl degradation: an $\mathrm{Ab}$ initio study of the relationship between peptide conformation and backbone NH acidity," Journal of the American Chemical Society, vol. 123, no. 15, pp. 3499-3506, 2001.

[26] C. Brückner, S.-C. Bunz, D. Imhof, C. Neusüß, and G. K. E. Scriba, "Isomerization and epimerization of the aspartyl tetrapeptide Ala-Phe-Asp-GlyOH at $\mathrm{pH}$ 10-A CE study," Electrophoresis, vol. 34, no. 18, pp. 2666-2673, 2013.

[27] A. D. Borthwick, "2,5-diketopiperazines: synthesis, reactions, medicinal chemistry, and bioactive natural products," Chemical Reviews, vol. 112, no. 7, pp. 3641-3716, 2012. 

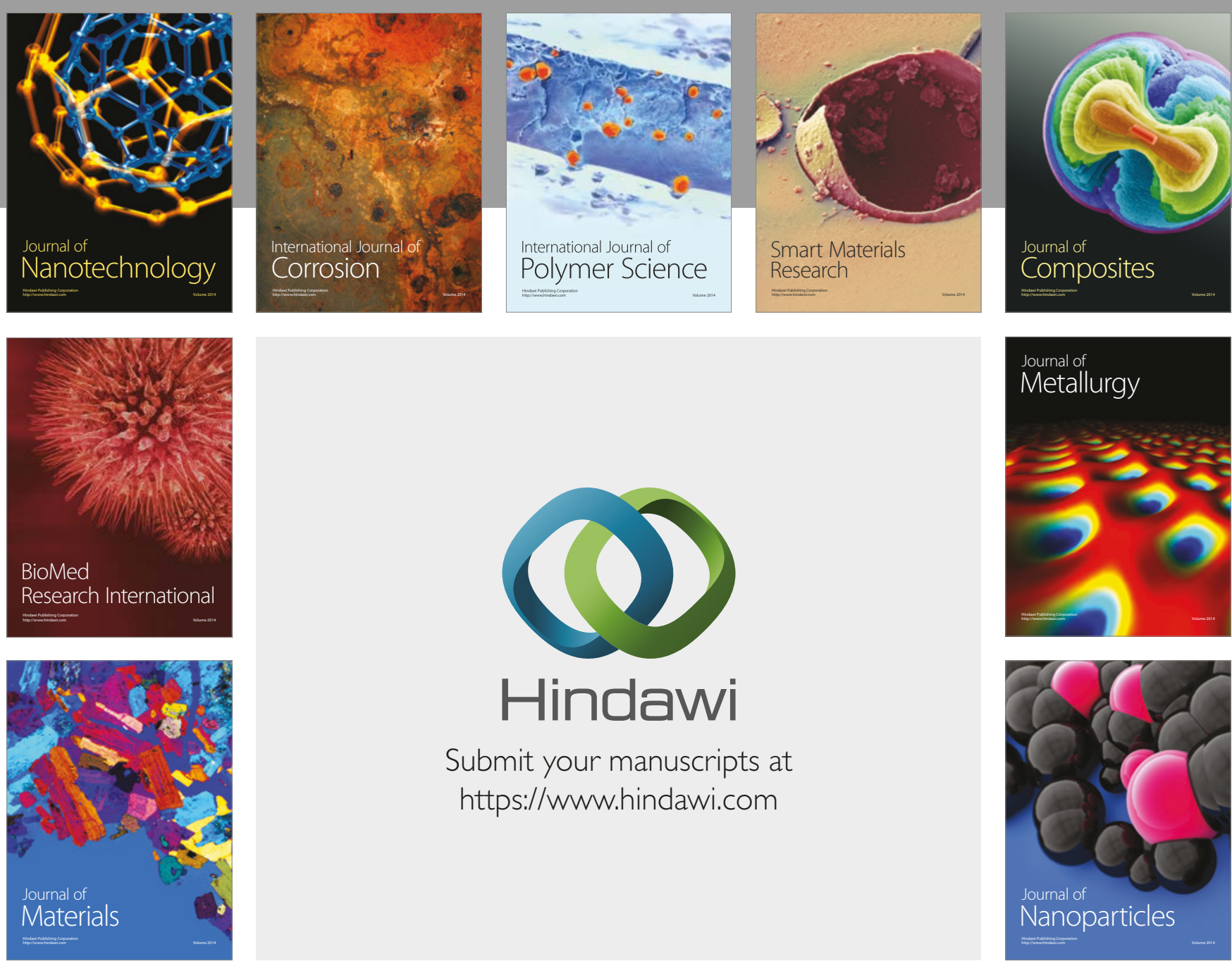

\section{Hindawi}

Submit your manuscripts at

https://www.hindawi.com
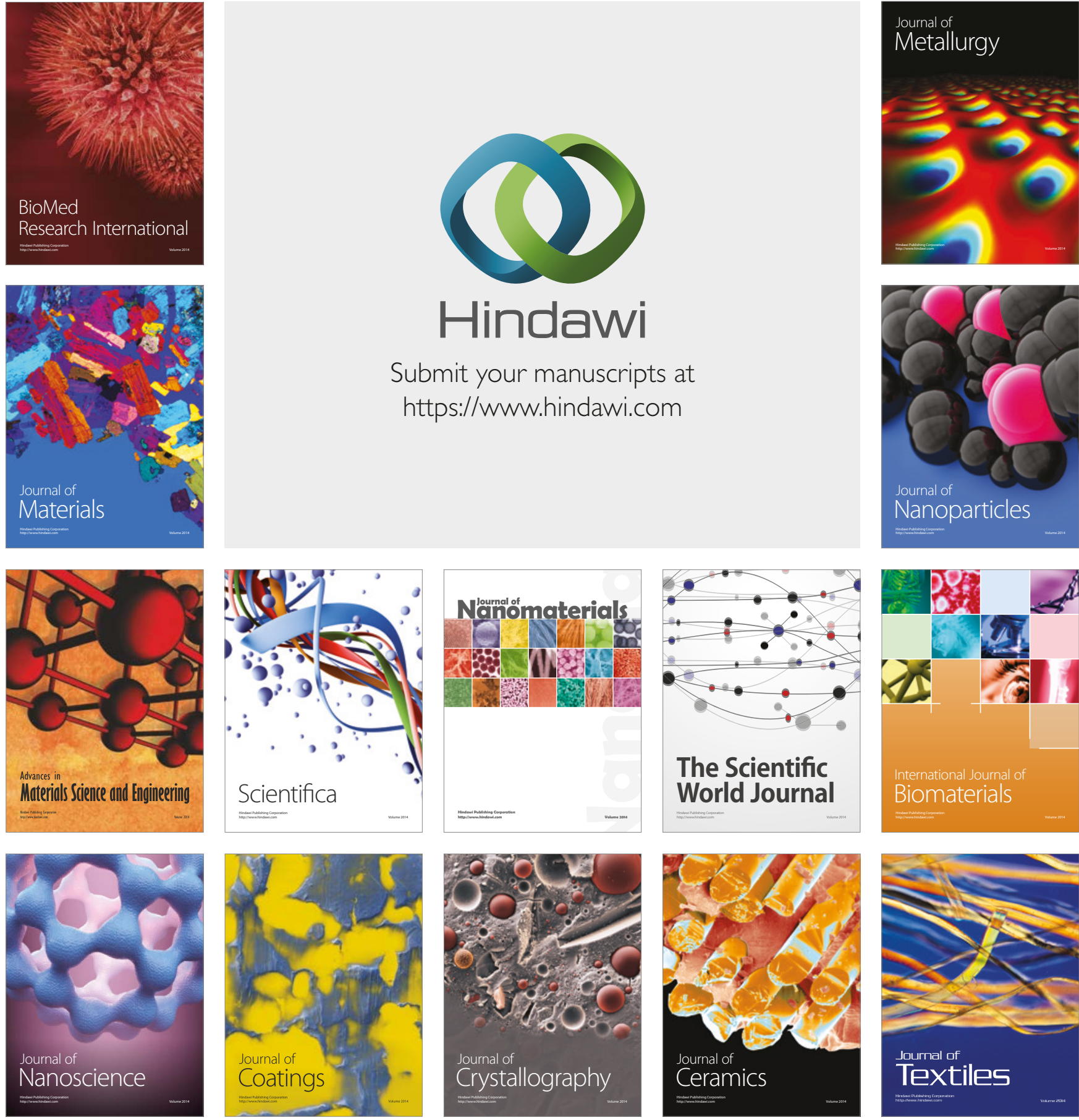

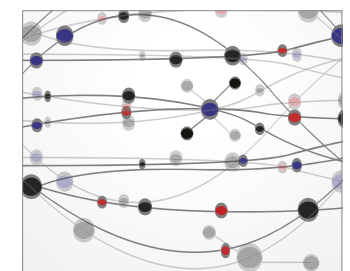

The Scientific World Journal
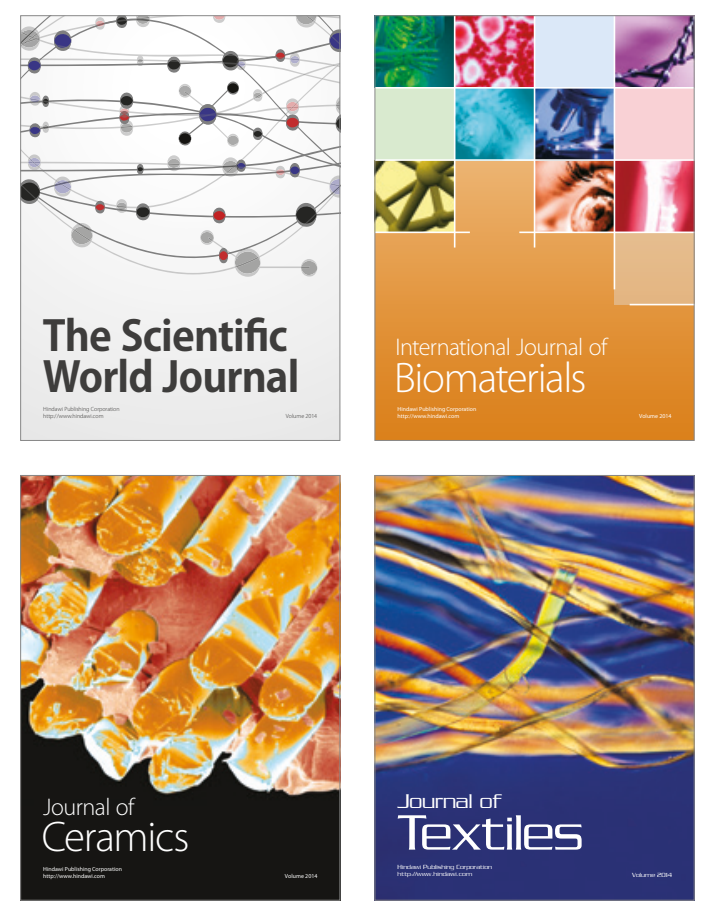